\title{
LOCAL GOVERNMENTS AND THE CROWN's DUTY TO CONSULT
}

\author{
Felix HoeHN $^{*}$ AND Michael Stevens ${ }^{* *}$
}

\begin{abstract}
Do municipal governments embody the Crown to the extent that they owe a duty to consult with Indigenous groups when a local government decision might detrimentally impact Aboriginal rights? The authors point to two legal trends: jurisprudential recognition of administrative bodies' ability to satisfy the duty in certain circumstances, and the expansion of the scope and role of municipal governments. The authors argue that when a province creates local governments with broad powers, the exercise of the powers conferred on the municipal governments are still subject to constitutional limits, such as the duty to consult. The article also highlights policy and practical considerations in support of this argument.
\end{abstract}

\section{TABLE OF CONTENTS}

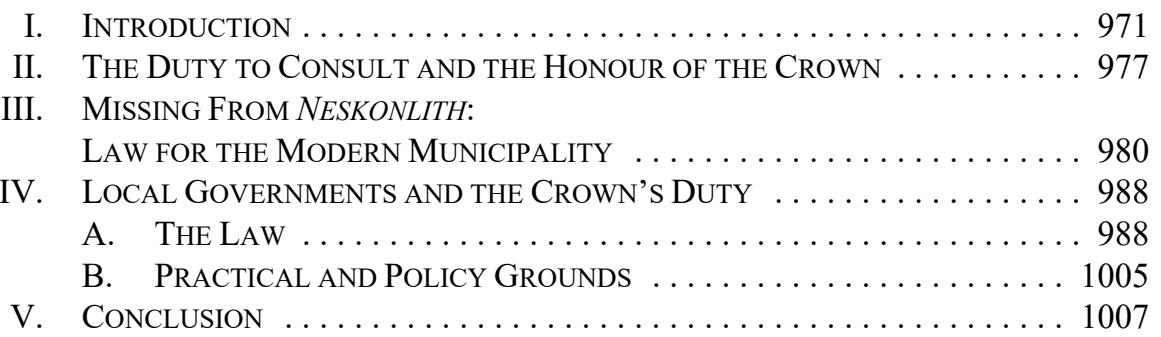

\section{INTRODUCTION}

We do live side by side and we need to work on a relationship to create or promote a common understanding among all our constituents ... I know that municipalities have a duty to consult, but I think that we need to find the best way forward to consult with each other, regardless of what legal obligations might exist. I mean, that's just neighbourly, right?

- Chief Percy Guichon, Chief of the Alexis Creek First Nation, one of the communities making up the Tsilhqot'in National Government, speaking to local community leaders at a convention of the Union of British Columbia Municipalities in September $2014 .^{1}$

This article will argue that Chief Guichon is right - local governments have a duty to consult. This is not just a legal obligation, it is also a prerequisite for reconciliation, or, as Chief Guichon put it, it's "just neighbourly." The Truth and Reconciliation Commission (TRC) underlined the importance of municipalities in the reconciliation process by including

** BA (Hon), LLB, LLM, College of Law, University of Saskatchewan.

JD, WMCZ Lawyers, Saskatoon, Saskatchewan. The authors thank Doug Harris, Drea Nasager, Edward Wensing, Norman Zlotkin, and the anonymous reviewers for their helpful comments on earlier drafts. Jeff Lee, "Tsilhqot'in Nation Strikes Conciliatory Note With Municipalities; Chiefs Insist Their Relationship Should Be 'Neighbourly,"' Vancouver Sun (24 September 2014) A6. Portions of this passage were also quoted in Truth and Reconciliation Commission of Canada, Canada's Residential Schools: Reconciliation: The Final Report of the Truth and Reconciliation Commission of Canada, vol 6 (Montreal: McGill-Queen's University Press, 2015) at 203, online: <nctr.ca/assets/reports/Final\%20 Reports/Volume_6_Reconciliation_English_Web.pdf $>$ [TRC vol 6]. 
them with other governments in several calls to action. ${ }^{2}$ Local governments should embrace their role in furthering reconciliation, and should not be heard to say that they are "a stranger to the Crown-First Nations relationship."3

Municipalities that consult with their Indigenous neighbours will further the dual objectives of the duty to consult: protecting Aboriginal ${ }^{4}$ and treaty rights, and furthering reconciliation between Aboriginal peoples and the Crown. ${ }^{5}$ Applying this duty to municipal governments also accords with the "generous, purposive approach that must be brought to the duty to consult." 6

Local governments have limited jurisdiction, and reconciliation between the Crown and Indigenous peoples will require nation-to-nation negotiations in which municipalities will have a limited role. However, people live in local communities, and the quality of the relationship between Canada's Indigenous peoples and settlers in those communities has a profound impact on reconciliation on a broader scale. The Supreme Court of Canada has said that consultation, in essence, is "talking together for mutual understanding." Conversations between neighbours have been a powerful force toward reconciling opposing perspectives, ${ }^{8}$ and have led to mutual social and economic benefits. An example of the latter is the municipal support of urban reserves in Saskatchewan. ${ }^{9}$

Ontario's Ministry of Municipal Affairs and Housing believes that "municipalities have a duty to consult in some circumstances," "and the Ministry has shown how consultation and cooperation between municipalities and Aboriginal governments has strengthened

See $T R C$ vol 6, ibid, calls to action 43, 47, 57, 75, calling on municipal and other governments to fully adopt and implement the United Nations Declaration on the Rights of Indigenous Peoples, GA Res 61/295, UNGAOR, 61st Sess, UN Doc A/61/295 (2007) [UNDRIP], to repudiate discovery and similar doctrines, to educate public servants on the history of Aboriginal peoples, and to work to identify, document, maintain, commemorate, and protect residential school cemeteries or other sites at which residential school children were buried.

3 This phrase was part of the City of Salmon Arm's successful argument that it did not have a duty to consult the Neskonlith Indian Band about a development permit for a shopping centre in Neskonlith Indian Band v Salmon Arm (City), 2012 BCCA 379, 354 DLR (4th) 696 at para 56 [Neskonlith], aff'g 2012 BCSC 499, [2012] 7 WWR 726 [Neskonlith BCSC].

4 While there may be good reasons to prefer the term "Indigenous" over "Aboriginal," this article will sometimes use "Aboriginal" because this term is used and defined in section 35 of the Constitution Act, 1982, being Schedule B to the Canada Act 1982 (UK), 1982, c 11. Section 35 reads as follows:

(1) The existing aboriginal and treaty rights of the aboriginal peoples of Canada are hereby recognized and affirmed.

(2) In this Act, "aboriginal peoples of Canada" includes the Indian, Inuit and Métis peoples of Canada.

(3) For greater certainty, in subsection (1) "treaty rights" includes rights that now exist by way of land claims agreements or may be so acquired.

Rio Tinto Alcan Inc v Carrier Sekani Tribal Council, 2010 SCC 43, [2010] 2 SCR 650 at paras 34, 46, 53 [Carrier Sekani].

$6 \quad$ Ibid at para 43. See also ibid at para 46.

$7 \quad$ Clyde River (Hamlet) v Petroleum Geo-Services Inc, 2017 SCC 40, [2017] 1 SCR 1069 at para 49 [Clyde River], citing Thomas Isaac \& Anthony Knox, "The Crown's Duty to Consult Aboriginal People" (2003) 41:1 Alta L Rev 49 at 61.

$8 \quad$ See e.g. Rebel Sky Media, "Reserve 107: Reconciliation on the Prairies" (2016), online: $<$ https://www. reserve107thefilm.com/>. Mennonites and Lutherans in Laird, Saskatchewan learned they were living on land that Treaty 6 had reserved for the Young Chippewayan First Nation, met with the Chief and descendants of the First Nation, and agreed to work together.

9 See generally F Laurie Barron \& Joseph Garcea, eds, Urban Indian Reserves: Forging New Relationships in Saskatchewan (Saskatoon: Purich, 1999).

10 Ontario, Ministry of Municipal Affairs and Housing, "Municipal-Aboriginal Relationships: Case Studies" (Toronto: Queen's Printer for Ontario, 2009) at 1, online: <www.mah.gov.on.ca/AssetFactory. aspx?did=6775> [Ontario, "Case Studies"]. 
relationships. ${ }^{11}$ In three cases, municipalities consulted with First Nations after their operations came across burial sites. York Region accommodated First Nations by realigning a major road to protect an ossuary, and the Town of Midland interrupted work on a municipal community centre and agreed to preserve and recognize the site. ${ }^{12}$ The City of Kingston and several First Nations agreed on strategies to protect a burial site on Belle Island. Kingston also committed to providing early notice and documentation of land use plans, and to consult on future projects. ${ }^{13}$

The value of ongoing collaboration and consultation between municipalities and First Nations was also evident in a forum created in 2001 by the City of Kenora and the Grand Council of Treaty \#3, representing several First Nations, and known as the "Common Land, Common Ground initiative." This initiative averted two potential conflicts over lands with strong significance for the First Nations. It was supported by a contribution from AbitibiConsolidated of valuable undeveloped land, and included joint management of the land by the Common Ground Working Group (CGWG), which operates by consensus and respects both Aboriginal and non-Aboriginal process requirements. ${ }^{14}$

Tragically, a failure to consult, to accommodate, and to build positive relationships at the local level has led to confrontations that have left ugly scars on the Canadian psyche. Two notable examples are Oka and Caledonia. Both conflicts were sparked by municipal decisions favouring the development of lands that were the subject of multi-generational grievances of First Nations. These conflicts sparked occupations and physical confrontations between the Canadian state and First Nations, and in Oka, northwest of Montreal, this resulted in the death of Corporal Marcel Lemay of the Sûreté du Québec. In Oka, the municipality planned to expand a golf course onto land claimed by the Mohawk, which included sacred resting grounds. In Caledonia, Ontario, Haldimand County Council had approved a subdivision on disputed land, ownership of which had previously been transferred from Caledonia to a private developer. ${ }^{15}$ Although both disputes were eventually settled after provincial and federal government involvement, disputes continue to simmer at both locations. ${ }^{16}$ A similar dispute involving a larger planned subdivision developed recently in Caledonia, ${ }^{17}$ and municipalities are still challenging provincial decisions made to resolve the Oka dispute. ${ }^{18}$

\section{Ibid.}

Ibid at 5-6.

Ibid at $9-10$.

Ibid at 7-8.

For further details, see Kathy L Brock, "From Oka to Caledonia: Assessing the Learning Curve in Intergovernmental Cooperation" (March 2010) (Paper delivered at the Canadian Political Science Association Meetings, Concordia University, Montreal, 1 June 2010) [unpublished] especially at 4, online: <https://www. cpsa-acsp.ca/papers-2010/Brock.pdf>; Laura DeVries, Conflict in Caledonia: Aboriginal Land Rights and the Rule of Law (Vancouver: UBC Press, 2011).

16 Julien Gignac, "Bitter Land Dispute Results in Blockade on Six Nations in Caledonia" The Star (30 August 2017), online: <https://www.thestar.com/news/canada/2017/08/30/bitter-land-dispute-results-inblockade-on-six-nations-in-caledonia.html>; Daniel J Rowe, "Highway 30 Decision Stands, No Appeal" Eastern Door (2 October 2017), online: <https://www.easterndoor.com/2017/10/02/highway-30decision-stands-no-appeal/>.

17 Teviah Moro, "Native Claims on Caledonia Housing Land Heat Up," The Hamilton Spectator (13 January 2016), online: <www.thespec.com>.

18 "South Shore Mayors Continue Legal Battle Over Disputed Mohawk Lands," CBC News (30 April 2017), online: <www.cbc.ca/news>. 
Municipalities can also find themselves in the middle of land claim disputes because the outcome will affect their jurisdiction over lands and taxation. ${ }^{19}$ Municipal and Indigenous interests will often intersect, and to avoid collisions, courts should affirm that local governments have a duty to take the constitutional rights of their Indigenous neighbours into account when making decisions that affect them.

While only the worst local conflicts will gain national attention, all relationships need nurturing. This evokes the warning of Supreme Court Justice Ian Binnie that

[t] he multitude of smaller grievances created by the indifference of some government officials to [A]boriginal people's concerns, and the lack of respect inherent in that indifference has been as destructive of the process of reconciliation as some of the larger and more explosive controversies. ${ }^{20}$

The importance of local governments in Canadian public life is often underestimated. Municipalities have been considered an inferior species of government because they lack constitutional status ${ }^{21}$ and so are "creatures of statute" 22 with no more powers than have been granted by those statutes. ${ }^{23}$

While it is important to understand the legal framework in which local governments exist, focusing soley on the lack of a direct constitutional mandate paints an incomplete picture of local governments in the twenty-first century. The authority of Canadian municipalities has grown as provinces reformed municipal statutes to underline the governmental role of municipalities, granting more authority to local governments and doing so in broad terms. ${ }^{24}$ The Supreme Court of Canada has recognized the importance of local self-government and

See e.g. Thessalon First Nation v Huron Shores, 2016 ONSC 2391, 54 MPLR (5th) 165; Jeff Gray, "Divisive Conflict at Sauble Beach Is Older Than Canada Itself," The Globe and Mail (30 August 2015), online: <www.theglobeandmail.com>.

20 Mikisew Cree First Nation v Canada (Minister of Canadian Heritage), 2005 SCC 69, [2005] 3 SCR 388 at para $1[$ Mikisew Cree $]$.

21 Section 92(8) of the Constitution Act, 1867 (UK), 30 \& 31 Vict, c 3, reprinted in RSC 1985, Appendix II, No 5 gives the legislature of each province exclusive authority over "Municipal Institutions in the Province." For a thoughtful challenge of the conventional view that municipalities are merely creatures of statute, and lack constitutional or inherent status as an essential part of a democratic society, see Warren Magnusson, “Are Municipalities Creatures of the Provinces?" (2005) 39:2 J Can Studies 5. Although municipalities have also been created by territorial statutes, for the sake of brevity the discussion below will simply refer to municipalities as the product of provincial statutes. For a discussion of municipal government reform in the territories, see Katherine AH Graham, "Municipal Reform in the Northern Territories: Now for Something Different" in Joseph Garcea \& Edward C LeSage Jr, eds, Municipal Reform in Canada: Reconfiguration, Re-Empowerment, and Rebalancing (Don Mills, Ont: Oxford University Press, 2005) 269. Graham observed that there are marked differences in the context of municipal government in the territories compared to southern Canada. Some of these are that the number of municipalities and their populations are much smaller, and the municipalities are generally isolated from one another. Since the territories and their governments are creations of federal statutes, territorial lands remain federal Crown lands, and most lands, even in municipalities, remain in public ownership. Finally, Aboriginal land claims have had substantial impacts on the development of municipal governments (Graham, ibid at 270-71).

$22 \quad$ Neskonlith, supra note 3 at para 8.

23 Stanley M Makuch, Neil Craik \& Signe B Leisk, Canadian Municipal and Planning Law, 2nd ed (Toronto: Thomson Canada, 2004) at 81; Felix Hoehn, Municipalities and Canadian Law: Defining the Authority of Local Governments (Saskatoon: Purich, 1996) at 1.

24 See generally Garcea \& LeSage, supra note 21. See also Andrew Sancton \& Robert Young, eds, Foundations of Governance: Municipal Government in Canada's Provinces (Toronto: University of Toronto Press, 2009); C Richard Tindal et al, Local Government in Canada, 8th ed (Toronto: Nelson Education, 2009). 
adopted a "broad and purposive approach" 25 to the interpretation of municipal powers. Municipalities come in many shapes and sizes, govern urban and rural territory, and perform essential functions, which normally include a dominant role in land use planning and jurisdiction over a wide range of matters that affect the daily lives of their citizens more than any other level of government. ${ }^{26}$ The populations of the larger municipalities in Canada exceed those of the smaller provinces. Over the past two decades, municipalities have matured to become governments in their own right, not mere administrators of provincial policy.

In view of their ubiquity and broad legislative powers, it is not surprising that some decisions of municipal governments will affect Aboriginal rights or conflict with the jurisdiction of Indigenous governments. The Supreme Court considered when administrative tribunals may be subject to the duty to consult in Carrier Sekani, ${ }^{27}$ and more recently in Clyde River ${ }^{28}$ and Chippewas of the Thames First Nation v. Enbridge Pipelines Inc. ${ }^{29}$ These cases revealed that a decision by an administrative body may trigger the Crown's duty to consult, and if the body has sufficient delegated powers, the body may fulfill the Crown's duty. ${ }^{30}$

The Supreme Court has not yet considered whether or how the duty to consult and accommodate applies to municipalities. Like municipalities, administrative bodies derive their powers from statute, and so the Supreme Court's view of how the duty to consult applies to administrative bodies is a useful indicator of how this duty may apply to municipalities. ${ }^{31}$ At the same time, a full consideration of how the Crown's duty to consult may apply to municipalities must take into account how they differ from administrative bodies. The main difference is that municipalities, unlike tribunals, are governments, and it is because they are governments that courts should find municipalities subject to the duty to consult.

In the most significant decision on point to date, Neskonlith, the British Columbia Court of Appeal held that the City of Salmon Arm was not subject to a duty to consult. The Court gave clear reasons for dismissing the appeal on the grounds that the Band's claim for interference with its rights was too speculative to have engaged the duty to consult, and that, in any event, the City had consulted adequately. However, the Court went further than it had

United Taxi Drivers' Fellowship of Southern Alberta v Calgary (City), 2004 SCC 19, [2004] 1 SCR 485 at paras 6-8, 11 [United Taxi].

According to Sancton \& Young, supra note 24 at 6-7, virtually all Canadian municipalities have at least some authority over fire protection, animal control, roads, traffic control, solid waste collection and disposal, land use planning and regulation, building regulation, economic development, tourism, libraries, parks, recreation and cultural facilities, business licensing, emergency planning, fences and drainage, cemeteries, and weed control. In addition, urban municipalities are generally responsible for policing, public transit, taxi regulation, water purification and distribution, sewage, and noise.

Supra note 5.

Supra note 7.

2017 SCC 41, [2017] 1 SCR 1099 [Chippewas of the Thames].

Carrier Sekani, supra note 5 at paras 31,55, 60; Clyde River, supra note 7 at paras 25, 30; Chippewas of the Thames, ibid at paras 29, 32 .

See e.g. Janna Promislow, "Irreconcilable?: The Duty to Consult and Administrative Decision Makers" (2013) 22:1 Const Forum Const 63; Kaitlin Ritchie, "Issues Associated With the Implementation of the Duty to Consult and Accommodate Aboriginal Peoples: Threatening the Goals of Reconciliation and Meaningful Consultation" (2013) 46:2 UBC L Rev 397; Shin Imai \& Ashley Stacey, "Municipalities and the Duty to Consult Aboriginal Peoples: A Case Comment on Neskonlith Indian Band v Salmon Arm (City)" (2014) 47:1 UBC L Rev 293. 
to by concluding that municipalities generally do not have the authority to consult and accommodate because they are "creatures of statute" and lack "practical resources" to do so. ${ }^{32}$ While local governments, like tribunals, owe their existence to statutes, unlike tribunals they are governments that make policy decisions and legislate over a wide range of matters. Local powers to control land use are the most obvious, but not the only example of powers that may affect Indigenous rights. This article will argue that when a province creates municipal governments with broad powers, these governments must exercise their powers subject to constitutional limitations and principles, including the duty to consult. In addition to legal grounds, strong practical and policy considerations also favour subjecting local governments to the duty to consult and accommodate.

If local governments are not included in the courts' conception of the "Crown," then they do not have the principal legal responsibility for consultation, because the honour of the Crown cannot be delegated. In Haida Nation v. British Columbia (Minister of Forests), the Supreme Court explained why the duty to consult only binds the Crown:

[T] the duty to consult and accommodate ... flows from the Crown's assumption of sovereignty over lands and resources formerly held by the Aboriginal group. This theory provides no support for an obligation on third parties to consult or accommodate. The Crown alone remains legally responsible for the consequences of its actions and interactions with third parties, that affect Aboriginal interests. ${ }^{33}$

In addition to Neskonlith, some other cases found municipal decisions not to have engaged the honour of the Crown because the municipality was a "third party," 34 or because local governments were "bound by their provincial enabling legislation." 35

If the governmental role of modern municipalities makes them part of the Crown or the Crown's agent, then they are directly subject to the duty to consult and accommodate. If not, they may still be subject to the duty if it is delegated by the provincial legislature, just as administrative tribunals may be subject to that duty. ${ }^{36}$ As discussed below, recent jurisprudence from the Supreme Court of Canada indicates that when considering the Crown's duties to Aboriginal peoples, the Supreme Court favours a broad conception of the "Crown" as including all government power. ${ }^{37}$

Above all, whether a municipality bears the Crown's duty to consult should be consistent with the honour of the Crown, which arises from the Crown's assumption of sovereignty

$32 \quad$ Neskonlith, supra note 3 at paras $70-71$.

33 Haida Nation v British Columbia (Minister of Forests), 2004 SCC 73, [2004] 3 SCR 511 at para 53 [Haida Nation].

34 Musqueam Indian Band v City of Richmond, 2005 BCSC 1069, 44 BCLR (4th) 326 at para 105 [Musqueam]. The petitioning Indian Band asked the Court to set aside the decision of the British Columbia Lottery Corporation to relocate and expand a gaming facility, and to quash the City's approval of this move and expansion. The Court interpreted Haida Nation, supra note 33, as determining that a third party "in the position of ... Richmond" did not have a duty to consult. However, the Court found that the Lottery Corporation was an agent of the Crown, and it had fulfilled its statutory obligation to consult with First Nations. Moreover, the matters that might have been the subject of accommodation were outside the jurisdiction of the municipality (Musqueam, ibid at paras 88-92, 105).

Gardner v Williams Lake (City), 2006 BCCA 307, 54 BCLR (4th) 225 at para 24.

Carrier Sekani, supra note 5 at paras 55-56.

Grassy Narrows First Nation v Ontario (Natural Resources), 2014 SCC 48, [2014] 2 SCR 447 at para 39 [Grassy Narrows]; Clyde River, supra note 7 at para 29; Chippewas of the Thames, supra note 29 at para 29. 
over lands and resources formerly held by the Indigenous nation. ${ }^{38}$ The powers delegated to local governments are the same powers assumed by the Crown over lands formerly controlled by Aboriginal peoples. When exercising those powers, local governments should do so in a manner consistent with the honour of the Crown.

\title{
II. The Duty to Consult And The Honour of The Crown
}

The duty to consult is rooted in the honour of the Crown. As explained by the Supreme Court of Canada in Haida Nation:

\begin{abstract}
The government's duty to consult with Aboriginal peoples and accommodate their interests is grounded in the honour of the Crown. The honour of the Crown is always at stake in its dealings with Aboriginal peoples.... It is not a mere incantation, but rather a core precept that finds its application in concrete practices. $^{39}$
\end{abstract}

Historically, the honour of the Crown originates from English law and was applied in situations in which courts were asked to interpret Crown grants. If more than one interpretation was available to the court, the interpretation to be preferred was the one that upheld the Crown's honour. ${ }^{40}$

More recently, the application of the honour of the Crown to the interpretation of Aboriginal rights has become a foundational principle in Canadian law. As explained by the Supreme Court of Canada in Beckman v. Little Salmon/Carmacks First Nation, the honour of the Crown is a constitutional principle which can be traced to the Crown recognizing its obligation of honourable dealing in the Royal Proclamation of 1763, in which the Crown pledged to protect Aboriginal peoples from exploitation. ${ }^{41}$ The Supreme Court has since affirmed the status of the honour of the Crown as a "constitutional principle" 42 which is engaged "in situations involving reconciliation of Aboriginal rights with Crown sovereignty." 43

The obligations that flow from the honour of the Crown depend on the nature of the dealings between the Crown and Aboriginal peoples. For example, the honour of the Crown requires good faith negotiation in treaties, ${ }^{44}$ and an avoidance of sharp practices in treaty interpretation. ${ }^{45}$ Additionally, and most importantly for the purposes of this article, the honour of the Crown gives rise to the Crown's duty to consult with Aboriginal peoples

\footnotetext{
Haida Nation, supra note 33 at para 32.

Ibid at para 16 [citations omitted].

See The Case of The Churchwardens of St Saviour in Southwark (1613), 77 ER 1025 (KB) at 1027; Roger Earl of Rutland's Case (1608), 77 ER 555. Both cases were cited by the Supreme Court's discussion of the history of the honour of the Crown in $R v$ Marshall, [1999] 3 SCR 456 at para 43 [Marshall]. See also Manitoba Métis Federation Inc v Canada (Attorney General), 2010 MBCA 71, [2010] 12 WWR 599 at paras 408-409; David M Arnot, "The Honour of the Crown" (1996) 60 Sask L Rev 339 at 340.

412010 SCC 53, [2010] 3 SCR 103 at para 42 [Little Salmon], citing Royal Proclamation, 1763 (UK), 3 Geo III, reprinted in RSC 1985, Appendix II, No 1.

42 Manitoba Metis Federation Inc v Canada (Attorney General), 2013 SCC 14, [2013] 1 SCR 623 at para 69 [Manitoba Metis], citing Little Salmon, ibid.

Manitoba Metis, ibid at para 68.

Haida Nation, supra note 33 at para 19

Ibid, citing $R$ v Badger, [1996] 1 SCR 771 at para 41; Marshall, supra note 40 at para 4.
} 
regarding proposed Crown conduct that may adversely affect an existing or potential Aboriginal right.

The honour of the Crown and the duty to consult also flow from section 35 of the Constitution Act, 1982, which recognizes and affirms Aboriginal and treaty rights. ${ }^{46}$ In Haida Nation, the Supreme Court held that section 35 represents a promise of rights recognition, and

[t]his promise is realized and sovereignty claims reconciled through the process of honourable negotiation. It is a corollary of s. 35 that the Crown act honourably in defining the rights it guarantees and in reconciling them with other rights and interests. This, in turn, implies a duty to consult and, if appropriate, accommodate. 47

Accordingly, the duty to consult is integral to the Crown's constitutional obligation to reconcile Aboriginal and non-Aboriginal interests.

At issue in Haida Nation was a tree-farming licence transferred from the provincial government to Weyerhaeuser, a large forestry firm. The Haida people claimed title to the land, but title had not yet been proven. On behalf of a unanimous Supreme Court, Chief Justice McLachlin held that the government had a legal duty to consult the Haida people before issuing the licence. ${ }^{48}$ She explained that the duty to consult arose "when the Crown [had] knowledge, real or constructive, of the potential existence of the Aboriginal right or title and contemplates conduct that might adversely affect it." 49 Therefore, there is a low threshold for triggering the duty to consult, ${ }^{50}$ and it is enough if a potential Aboriginal right may be affected.

The duty to consult has two main objectives: protecting Aboriginal rights from adverse Crown conduct and promoting reconciliation. As noted above, in Haida Nation, the Chief Justice observed that section 35 represents a promise of rights recognition through honourable negotiation to define those rights, and that this implies a duty to consult and accommodate ${ }^{51}$ From this, it can be inferred that the duty arises to protect those rights from being ignored, infringed, or lost. Chief Justice McLachlin expanded on this in Carrier Sekani ${ }^{52}$ when she wrote that the duty to consult comes from the need to protect claimed or proven Aboriginal rights from being impinged on by proposed actions. Otherwise, an Indigenous people would have to seek injunctions or other expensive and often ineffective remedies in the courts. ${ }^{53}$

In Haida Nation, reconciliation was also identified as an objective of the honour of the Crown and the duty to consult. The promise of rights recognition would see "sovereignty

See supra note 4.

Supra note 33 at para 20.

Ibid at para 10 .

Ibid at para 35

See Anna Fung, Anne Giardini \& Rob Miller, “A Decade Since Delgamuukw: Update From an Industry Perspective" in Maria Morellato, ed, Aboriginal Law Since Delgamuukw (Aurora, Ont: Canada Law Book, 2009) 205 at 210.

See supra note 47 and accompanying text.

Supra note 5.

Ibid at para 33 . 
claims reconciled" and the Crown acting honourably in defining Aboriginal rights and "reconciling them with other rights and interests." In another case that applied the duty to consult, the Supreme Court described the fundamental purpose of the law of Aboriginal and treaty rights as "the reconciliation of [A]boriginal peoples and non-[A]boriginal peoples and their respective claims, interests and ambitions." 55

The Supreme Court in Haida Nation described the duty to consult and accommodate as "part of a process of fair dealing and reconciliation that begins with the assertion of sovereignty and continues beyond formal claims resolution." ${ }^{, 56}$ The Supreme Court described reconciliation as a process rather than a final remedy; a process which flows from rights guaranteed in section 35 and the honour of the Crown, "which arises in turn from the Crown's assertion of sovereignty over an Aboriginal people and de facto control of land and resources that were formerly in the control of that people. ${ }^{.57}$ This passage suggests that it was the Crown's unilateral assertion of sovereignty over Aboriginal peoples that gave rise to the need for reconciliation, and the honour of the Crown and its ancillary duty to consult are necessary means to that end. ${ }^{58}$

The duty to consult furthers the goal of reconciliation by requiring dialogue and a search for outcomes respectful of the interests of all. As Sarah Burningham explains, "[C]onsultation, if undertaken with a mind to reconciliation and a genuine desire to achieve consensus, will lead the parties to search for mutually acceptable solution which will involve negotiation and compromise. ${ }^{\circ 9}$ Any analysis of the duty to consult must be done with the purpose of reconciliation kept in mind.

A strong argument can be made for interpreting the ambit of the "Crown" broadly to include local governments. For example, the Supreme Court has stated that due to its historical roots, the honour of the Crown should be understood "generously," "cannot be interpreted narrowly or technically, but must be given full effect in order to promote the process of reconciliation mandated by s. 35(1) [of the Constitution Act, 1982]." "61 Lori Sterling and Peter Landmann explain that excluding bodies exercising broad governmental powers from the ambit of the honour of the Crown "could create a gap between the decision-making activities of front line regulatory bodies and the locus of constitutional responsibility for the duty in provincial ministries." ${ }^{62}$ This could make the duty

54 Haida Nation, supra note 33 at para 20. See also supra note 47 and accompanying text.

Mikisew Cree, supra note 20 at para 1.

Haida Nation, supra note 33 at para 32.

Ibid.

For a consideration of theoretical approaches to the duty to consult, see Dwight G Newman, Revisiting the Duty to Consult Aboriginal Peoples (Saskatoon: Purich, 2014) at 23-35. On the purpose of the duty to consult, see also Chris W Sanderson, Keith B Bergner \& Michelle S Jones, "The Crown's Duty to Consult Aboriginal Peoples: Towards an Understanding of the Source, Purpose, and Limits of the Duty" (2012) 49:4 Alta L Rev 821 at 825-29.

59 Sarah Burningham, "Relationships and Remedies: How the Duty to Consult Can Contribute to a Renewed Aboriginal-Crown Relationship" in Student Public Policy Essays 2008-2009 (Regina: Johnson Shoyama Graduate School of Public Policy) 5 at 12.

$60 \quad$ Haida Nation, supra note 33 at para 17.

61 Taku River Tlingit First Nation v British Columbia (Project Assessment Director), 2004 SCC 74, [2004] 3 SCR 550 at para 24 [Taku River].

62 Lori Sterling \& Peter Landmann, "The Duty to Consult Aboriginal Peoples: Government Approaches to Unresolved Issues" in David A Wright \& Adam M Dodek, eds, Public Law at the McLachlin Court: The First Decade (Toronto: Irwin Law, 2011) 235 at 244. 
difficult to meet at an operational level, ${ }^{63}$ and is inconsistent with reconciliation, one of the objectives of the duty to consult.

\section{MISSING FROM NESKONLITH: LAW FOR THE MODERN MUNICIPALITY}

In Neskonlith, the British Columbia Court of Appeal found that the City of Salmon Arm had no duty to consult with the Neskonlith Indian Band regarding the City's granting of an Environmentally Hazardous Area Development Permit to a shopping centre on private land. ${ }^{64}$ Although the Court did not rule out the possibility that a local government could be subject to the duty to consult if this were delegated by statute, ${ }^{65}$ the Court went beyond the specific appeal before it to extrapolate that municipalities are not suitable subjects for the duty, even though this might make it more difficult to defend Aboriginal rights:

[W]hile it is true that First Nations may experience difficulty in seeking appropriate remedies in the courts in cases like this one, it is also true that as creatures of statute, municipalities do not in general have the authority to consult with and if indicated, accommodate First Nations as a specific group in making the dayto-day operational decisions that are the diet of local governments. ${ }^{66}$

This reference to the "diet" of local governments consisting of "day-to-day operational decisions" is not the only betrayal of the Court's impoverished view of today's local governments. For example, the Court described local governments as incapable of meeting the responsibilities of consultation with Indigenous peoples because they "lack the practical resources to consult and accommodate." ${ }^{67}$ The Court also rejected the prospect of what it considered a " "push-down' of the Crown's duty to consult" to local governments, because it would be "impractical" to have this duty "thrashed out in the context of the mundane decisions regarding licenses, permits, zoning restrictions and local by-laws." 68 The Court elaborated that municipal decisions

ranging from the issuance of business licences to the designation of parks, from the zoning of urban areas to the regulation of the keeping of animals, require efficiency and certainty. Daily life would be seriously bogged down if consultation — including the required "strength of claim" assessment — became necessary whenever a right or interest of a First Nation "might be" affected. ${ }^{69}$

The manner in which the Court described the function and activities of municipalities reflects an outdated theory of local government which views municipalities as no more than apolitical efficient administrators of provincial policy. This view of local government has been replaced, in theory and in law, with an understanding that municipalities are governments responsible for making and executing important policy decisions, and for

63 Ibid.

$64 \quad$ Supra note 3 at paras 3, 70.

65 The Court acknowledged the duty could be delegated by statute at the same time that it rejected the Band's argument that the duty attached "not because [it had been] delegated, but 'automatically' because the municipality is making a decision said to affect Aboriginal rights or interests" (ibid at para 68).

Ibid at para 70 .

Ibid at para 71 [emphasis in original].

Ibid at para 72 .

Ibid. 
designing and delivering services, all in a manner responsive to the needs and priorities of the local electorate. ${ }^{70}$

The traditional view of municipalities was that the delegated nature of their authority made them an inferior species of government. The consequences of their delegated authority was explained in East York (Borough) v. Ontario (Attorney General): (1) they lack constitutional status; (2) they are creatures of the legislature and exist only by virtue of provincial legislation; (3) they have no independent autonomy — legislation may abolish or repeal municipal powers; and (4) they can only exercise powers conferred by statute. ${ }^{71}$

East York accurately describes the limits of municipal authority. However, this should be the beginning and not the end of an analysis of the role and authority of municipalities, so as not to exaggerate the importance of their inferior constitutional status. The powers of Canada's federal and provincial governments are also subject to substantial constitutional limitations and were initially delegated by statutes of the Parliament of the United Kingdom. $^{72}$

In the past, statutes creating municipalities typically did not set out the purpose of those municipalities. At best, municipal purposes could be deduced from the powers granted in the statute. Traditionally these powers were cast in narrow, prescriptive terms, so it followed that the purposes of local governments were narrow and limited. Moreover, the courts relied on "Dillon's rule" to construe delegated powers narrowly. The effect of the rule, as one oftencited case put it, was that "[a]ny fair reasonable doubt concerning the existence of power is resolved by the courts against the corporation, and the power is denied."

Since the legislation also provided for elected councils, it must have intended to give some discretion over local policies and priorities to local governments. Kenneth Grant Crawford described these two potentially contradictory purposes of municipalities:

\footnotetext{
One is to carry out the duties imposed upon local authorities by the provinces which have created them, and to which they are ultimately answerable. The other is to carry out the wishes of the inhabitants of the area under their jurisdiction, within the scope and to the extent permitted by law. Opinions differ as to which of these two purposes should be dominant, although legally and constitutionally, if not politically, the priority of the former cannot be questioned. ${ }^{74}$
}

Crawford wrote this in 1954, and at that time, it would have been difficult to argue with his view that municipalities were mainly administrators of provincial policy. Municipalities depend on provincial legislation for their powers, and at that time the delegated powers were specific and narrow. "Dillon's rule" meant that any uncertainty in the scope of municipal

at $2-5$

$71 \quad$ East York (Borough) v Ontario (Attorney General) (1997), 34 OR (3d) 789 at $797-98$ (Gen Div), aff'd (1997) 36 OR (3d) 733 (CA), leave to appeal to SCC refused, 26385 (2 April 1998) [East York]. Constitution Act, 1867, supra note 21; Canada Act 1982 (UK), 1982, c 11.

Ottawa Electric Light Company v Corporation of the City of Ottawa (1906), 12 OLR 290 at 299 (CA), citing John F Dillon, Commentaries on the Law of Municipal Corporations, 4th ed, vol 1 (Boston: Little, Brown, \& Co, 1890), § 89.

74 Kenneth Grant Crawford, Canadian Municipal Government (Toronto: University of Toronto Press, 1954) at 3. 
authority would be resolved against the municipality. This cast municipalities mainly as administrators of provincial policy.

Some suggested that municipalities existed because central governments did not want to have to deal with everything themselves, and found local governments a convenient way to provide certain services. ${ }^{75}$ This view is consistent with the inferior legal status of municipalities, and with a narrow conception of the purpose of local governments. However, this fails to capture the scope of authority and the important governmental role of municipalities in the twenty-first century.

Recent legislative reform and Supreme Court of Canada decisions have widened the scope of municipal power, and have increasingly recognized municipalities as an order of government with a crucial role in Canadian democratic government. This began with the dissent of Justice McLachlin (as she then was) in Shell Canada Products Ltd. v. Vancouver (City), which called on courts to show greater deference to the decisions of local governments: ${ }^{76}$

Recent commentary suggests an emerging consensus that courts must respect the responsibility of elected municipal bodies to serve the people who elected them and exercise caution to avoid substituting their views of what is best for the citizens for those of municipal councils. Barring clear demonstration that a municipal decision was beyond its powers, courts should not so hold. ${ }^{77}$

This passage was cited with approval in several subsequent Supreme Court decisions, including United Taxi ${ }^{78}$ and 114957 Canada Ltée (Spraytech, Société d'arrosage) v. Hudson (Town). ${ }^{79}$ In Spraytech, Justice L'Heureux-Dubé, writing for the majority, commented on the importance of local governments and the principle of "subsidiarity":

The case arises in an era in which matters of governance are often examined through the lens of the principle of subsidiarity. This is the proposition that law-making and implementation are often best achieved at a level of government that is not only effective, but also closest to the citizens affected and thus most responsive to their needs, to local distinctiveness, and to population diversity. ${ }^{80}$

The Supreme Court recently explained how the governmental role of municipalities distinguishes them from quasi-judicial administrative tribunals:

\footnotetext{
Municipal councillors passing bylaws fulfill a task that affects their community as a whole and is legislative rather than adjudicative in nature. Bylaws are not quasi-judicial decisions. Rather, they involve an array of social, economic, political and other non-legal considerations. "Municipal governments are democratic institutions ", [per] LeBel J. for the majority in Pacific National Investments Ltd. v. Victoria (City), 2000 SCC 64, [2000] 2 S.C.R. 919, at para. 33. In this context, reasonableness means courts must respect the

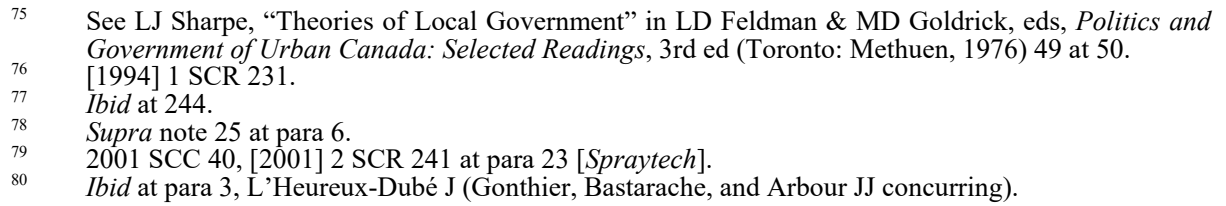


responsibility of elected representatives to serve the people who elected them and to whom they are ultimately accountable. $^{81}$

A crucial step in establishing municipalities as a respected order of government in Canada has been legislative reform, which changed the legal foundation for municipalities so much that today, Crawford's hierarchy of municipal roles must be reversed. Although local governments still lack constitutional status, municipal enabling statutes now emphasize and facilitate the democratic, governmental function of municipalities over their role as administrators of provincial policies.

The first major reform of municipal enabling statutes was Alberta's Municipal Government Act, ${ }^{82}$ which came into force in 1995 . This became a model for reforms in many other jurisdictions. The Act set out the purposes of a municipality, and the first was "to provide good government." Other purposes included providing such services and things that council considered desirable, and "to develop ... safe and viable communities."

Similar statements of municipal purpose can be found in newer statutes in almost all other jurisdictions ${ }^{84}$ Many of the newer core municipal statutes also recognize municipalities as an order or level of government. ${ }^{85}$ This could be viewed as merely symbolic, since only constitutional status would truly protect municipal jurisdiction from provincial infringement. Still, it has the force of law and is an aid to interpreting the powers granted in the statute. It also reminds the provinces and the courts that they should treat municipalities as governments that are primarily accountable to their electorates. An elaborate statement of this type is in British Columbia's Community Charter:

1 (1) Municipalities and their councils are recognized as an order of government within their jurisdiction that

(a) is democratically elected, autonomous, responsible and accountable,

Catalyst Paper Corp v North Cowichan (District), 2012 SCC 2, [2012] 1 SCR 5 at para 19 [emphasis added] [Catalyst Paper].

SA 1994, c M-26.1 [MGA 1994 (Alta)], now RSA 2000, c M-26 [MGA (Alta)].

MGA 1994 (Alta), ibid, s 3.

See e.g. Local Government Act, RSBC 2015, c 1, s 1 [LGA 2015 (BC)]; Community Charter, SBC 2003, c 26, ss 3, 7; Municipal Act, RSY 2002, c 154, s 3 [Municipal Act (YT)]; Municipal Act, 2001, SO 2001, c 25, s 2 [Municipal Act, 2001 (Ont)]; The Cities Act, SS 2002, c C-11.1, s 4(2) [Cities Act (Sask)]; The Municipalities Act, SS 2005, c M-36.1, s 4(2) [Municipalities Act (Sask)]; The Municipal and Various Acts Amendment Act, SM 1996, c 58, s 3 [Municipal Act (Man)]; The City of Winnipeg Charter Act, SM 2002, c 39, s 5(1) [Winnipeg Charter]; Municipal Government Act, SNS 1998, c 18, s 2(c) [MGA (NS)]; Municipal Powers Act, CQLR c C-47.1, s 2 [Municipal Powers Act (Que)]. At the time of writing, two further provinces are on the verge of bringing into force modern municipal acts that include similar purpose statements: see Bill 58, Municipal Government Act, 2nd Sess, 65th Leg, Prince Edward Island, 2016, cls 2-3 (assented to 15 December 2016), SPEI 2016, c C-44; Bill 44, Local Governance Act, 3rd Sess, 58th Leg, New Brunswick, 2016-2017, cl 5 (assented to 5 May 2017), SNB 2017, c 18. This leaves municipal statutes in Newfoundland and Labrador as the principal exception.

See e.g. MGA (NS), ibid ("a responsible order of government accountable to the people," Preamble); LGA 2015 (BC), ibid (recognizing "regional districts are an independent, responsible and accountable order of government within their jurisdiction,"s 185). For similar provisions, see Cities Act (Sask), ibid, s 3(1)(a); Municipal Act (YT), ibid, Preamble. The Municipal Act, 2001 (Ont), ibid, s 2 and the Winnipeg Charter, ibid, s 5(2), recognize municipalities as "responsible and accountable" governments. 
(b) is established and continued by the will of the residents of their communities, and

(c) provides for the municipal purposes of their communities. ${ }^{86}$

In the following section, "the Provincial government recognizes" that municipalities need, among other things, "(a) adequate powers and discretion to address existing and future community needs," and "(b) authority to determine the public interest of their communities, within a legislative framework that supports balance and certainty in relation to the differing interests of their communities."

In Neskonlith, the British Columbia Court of Appeal acknowledged the "aspirational wording of s. 1 of the Community Charter," but this did not persuade the Court that the City of Salmon Arm was subject to the duty to consult. ${ }^{88}$ This refusal to acknowledge the status of municipalities as set out in the statute is consistent with the comments of the Court referenced above revealing a narrow, more traditional view of the role of municipalities. ${ }^{89}$ The Court attempted to rebut these governmental aspirations by suggesting that municipalities "lack the practical resources to consult and accommodate." ${ }^{90}$ It described municipalities as varying "greatly in size and tax-base," and as being "generally concerned with the regulation of privately-owned land," with "Crown land and natural resources ... remain[ing] within the purview of the Province." 91

Oddly, neither of the Court of Appeal's two principal reasons for finding municipalities inappropriate for bearing the duty to consult — that their jurisdiction is too limited to raise the need to consult, or that, in any event, municipalities would lack the ability to do so applied in the case before it. First, the Band's claim of interference with its rights arose out of the City's use of its regulatory powers over the use of private land under the Local Government Act, ${ }^{92}$ so the City's lack of ownership of Crown lands was irrelevant. ${ }^{93}$ The Court also found that, in any event, the Band's claim for interference was too speculative to have engaged the duty to consult. ${ }^{94}$ It may be that municipal actions are less likely to adversely affect Aboriginal rights than provincial or federal decisions, but this is no reason for finding the duty should not bind municipalities when the threat to rights is real. Raising the spectre of a duty to consult arising from "mundane decisions" like business licences, park designations, and animal regulation ${ }^{95}$ is to attack a straw man, since such decisions are no

Supra note 84, s 1(1).

Ibid, s 1(2).

Supra note 3 at para 71.

See supra note 32 and accompanying text.

Neskonlith, supra note 3 at para 71 [emphasis in original].

Ibid.

RSBC 1996, c 323 [LGA 1996 (BC)] (now LGA 2015 (BC), supra note 84). The sections relevant to this discussion remain materially the same, and will be cited to both the previous and the current statute.

As Janna Promislow observed, even if the question is not completely settled, the duty to consult has been found to apply in relation to activities on private land (supra note 31 at 73, n 96, citing Hupacasath First Nation v British Columbia (Minister of Forests), 2005 BCSC 1712, [2006] 1 CNLR 22; John Voortman \& Associates Ltd v Haudenosaunee Confederacy Chiefs Council, [2009] 3 CNLR 117 (Ont Sup Ct J); Paul First Nation v Parkland (County), 2006 ABCA 128, [2006] 3 CNLR 243). Promislow also noted that treaty rights may be exercised on private lands where there is no visible, incompatible use of those lands, citing $R v$ Badger, supra note 45 .

94 Neskonlith, supra note 3 at paras 74-83.

Ibid at para 72 . 
more likely to engage Aboriginal rights than mundane decisions made by other levels of government.

Like most municipalities in Canada, the City of Salmon Arm enjoys broad powers related to land use regulation. Moreover, as the Court of Appeal acknowledged, the City's powers at issue related primarily to flood hazard management under section 910 of LGA 1996 (BC) ${ }^{96}$ which was enacted when the province transferred much of its responsibility over flood management to municipalities. ${ }^{97}$ This transfer was intended to enhance "local responsibility and control" over flood hazard management issues. ${ }^{98}$ While the Court's finding that the Indian Band's claim was too speculative was well-grounded, broad municipal authority over land use regulation in general, and flood management in particular, means that some local regulatory decisions are bound to have more than a speculative effect on Aboriginal rights.

The Court of Appeal's second major objection, that municipalities are not capable of fulfilling the duty to consult, sits uncomfortably with the Court finding, in the further alternative, that if the City had a duty to consult and it had been triggered, then the City had consulted adequately. ${ }^{99}$ In particular, the Court concluded the City had followed a reasonable process, and had "fully and promptly informed" the Neskonlith of the permit application and the development. ${ }^{100}$ The City had given the Neskonlith "several opportunities to express their concerns," had taken objections made by the Neskonlith and others seriously, and those objections had led "to material modifications of the ... development."101

In view of these facts, it is not surprising that the City did not argue that it lacked the practical resources to consult or accommodate - its position was simply that it had no legal obligation to do so. Municipalities would be hard-pressed to make an argument based on an inability to consult in relation to planning powers, since statutes delegating land use regulatory authority to municipalities invariably mandate minimum public participation requirements before making major discretionary decisions, such as the approving of statutory plans and zoning bylaws. For example, before the shopping centre could obtain the disputed approval of the development permit, it had to obtain an amendment to the City's official community plan (OCP) as well as a zoning bylaw amendment. The $L G A 1996$ (BC) required local governments to provide appropriate opportunities for consultation when developing, repealing, or amending an OCP. ${ }^{102}$ In fact, the local government is required to "specifically consider whether consultation is required with ... first nations." 103 Indeed, the Court of Appeal acknowledged that the City was presumably acting under this requirement of the LGA 1996 (BC) when it sought the views of the Neskonlith regarding the shopping centre developer's application to amend the OCP. ${ }^{104}$ Also, public hearings must be held on zoning

Supra note 92 (now LGA 2015 (BC), supra note 84, s 524).

Neskonlith, supra note 3 at para 10.

Ibid, citing British Columbia, Legislative Assembly, Official Report of Debates of the Legislative Assembly (Hansard), 37th Parl, 4th Sess, vol 16, No 12 (8 October 2003) at 7279 (Hon Joyce Murray). Neskonlith, ibid at para 84.

Ibid at para 90 .

Ibid.

LGA 1996 (BC), supra note 92, s 879 (now LGA 2015 (BC), supra note 84, s 475).

LGA 1996 (BC), ibid, s 879(2)(b)(iv) (now LGA 2015 (BC), ibid, s 475(2)(b)(iv)).

Neskonlith, supra note 3 at para 25. 
bylaws unless the proposed bylaw is consistent with an OCP that is in effect. ${ }^{105}$ In addition, the City's own bylaw included certain procedural requirements for granting a development permit, including public notice and public "input."

The Court of Appeal also buttressed its view that municipalities are incapable of fulfilling the obligations associated with the duty to consult by citing the Supreme Court's comments in Carrier Sekani that any tribunal charged with the obligation to consult would require remedial powers. ${ }^{107}$ The Court of Appeal stated:

\begin{abstract}
Such powers have not been granted to municipalities, just as they have not been granted to quasi-judicial tribunals. As the third order of government, municipal councils are simply not in a position to, for example, suspend the application of bylaws or the terms of OCPs, grant benefits to First Nations or indeed to consider matters outside their statutory parameters.... A fortiori, local governments lack the authority to engage in the nuanced and complex constitutional process involving "facts, law, policy and compromise" referred to in [Carrier Sekani]. ${ }^{108}$
\end{abstract}

Once again, the Court's approach appears to be coloured by its view that municipalities are confined to a limited role with narrow powers. The contrast with the Supreme Court's description of the role of modern municipalities is stark. The suggestion that consultation would be fruitless also contradicts the extensive public participation requirements already built into municipal statutes, especially in relation to land use regulation powers, as discussed above. ${ }^{109}$ Even though these processes may have been originally designed for a different purpose, they can be relied on by the Crown to fulfill the duty to consult as long as they result in an appropriate level of consultation. ${ }^{110}$

Also important for answering the Court of Appeal's concerns that municipal powers are too limited to be able to adequately consult and accommodate is the greater breadth and flexibility of municipal authority granted in modern municipal statutes, in contrast to the narrow, prescriptive grants of authority that dominated for almost all of the twentieth century.

Modern municipal statutes feature broadly worded grants of power, or spheres of jurisdiction. These give municipalities flexible powers to address local problems and priorities. For example, Alberta confers jurisdiction to pass bylaws for municipal purposes in general terms. ${ }^{111}$ This approach now dominates municipal enabling statutes across

LGA 1996 (BC), supra note 92, ss 890(1), (4) (now LGA 2015 (BC), supra note 84, s 464).

Neskonlith, supra note 3 at para 14.

Ibid at para 68, citing Carrier Sekani, supra note 5.

Neskonlith, ibid [citations omitted].

For an illuminating account of the importance and the challenges of consultation in this context, see the account of Tsleil-Waututh Nation involvement in a major update of the OCP of the District of North Vancouver in Libby Porter \& Janice Barry, Planning for Coexistence?: Recognizing Indigenous Rights Through Land-Use Planning in Canada and Australia (Milton Park, UK: Routledge, 2016) at 110-14. Clyde River, supra note 7 at para 31.

$M G A$ (Alta), supra note 82, s 7, includes, in part, the following substantive matters:

(a) [T]he safety, health and welfare of people and the protection of people and property;

(b) people, activities and things in, on or near a public place or place that is open to the public;

(c) nuisances, including unsightly property;

(d) transport and transportation systems;

(e) businesses, business activities and persons engaged in business; 
Canada. ${ }^{12}$ Alberta's Act underlines that the power to pass bylaws "is stated in general terms" to

(a) give broad authority to councils and to respect their right to govern municipalities in whatever way the councils consider appropriate, within the jurisdiction given to them under this or any other enactment, and

(b) enhance the ability of councils to respond to present and future issues in their municipalities. ${ }^{113}$

A crucial test of the effectiveness of spheres of jurisdiction came in United Taxi, ${ }^{114}$ a challenge of Calgary's authority to limit the number of taxi plate licences. None of the provisions of previous legislation dealing with the taxi industry and granting specific authority to limit the number of taxi licences were included in the new Act. The City argued that this authority now flowed from general grants of authority.

The Supreme Court unanimously held that the authority to regulate the taxi industry necessarily implied the authority to limit the number of taxi plate licences. ${ }^{115}$ The decision affirmed that the scope of municipal powers should no longer be interpreted narrowly:

\begin{abstract}
The evolution of the modern municipality has produced a shift in the proper approach to the interpretation of statutes empowering municipalities... The "benevolent" and "strict" construction dichotomy has been set aside, and a broad and purposive approach to the interpretation of municipal powers has been embraced.... This interpretive approach has evolved concomitantly with the modern method of drafting municipal legislation. Several provinces have moved away from the practice of granting municipalities specific powers in particular subject areas, choosing instead to confer them broad authority over generally defined matters....This shift in legislative drafting reflects the true nature of modern municipalities which require greater flexibility in fulfilling their statutory purposes. ${ }^{116}$
\end{abstract}

The Supreme Court's “broad and purposive approach” to interpretation makes it less likely that courts will invalidate the actions of local governments. The result, as the Supreme Court pointed out, is that reformed enabling legislation and the modern interpretive approach of the courts work in harmony to give municipalities greater flexibility in fulfilling their purposes.

Finally, when considering whether municipalities have capacity to consult and accommodate, it is worth considering the example of New Zealand, where local governments, generally comparable with Canadian municipalities, must consult with Maori on anything that may affect their rights and interests. These governments must also establish

(f) services provided by or on behalf of the municipality;

(g) public utilities;

(h) wild and domestic animals and activities in relation to them.

See e.g. LGA 2015 (BC), supra note 84, ss 187, 335; Community Charter, supra note 84, s 8; Cities Act (Sask), supra note 84, s 8; Municipalities Act (Sask), supra note 84, s 8; Municipal Act (Man), supra note 84, ss 231-36; Winnipeg Charter, supra note 84, ss 6-7, 128-68; Municipal Act, 2001 (Ont), supra note 84, ss 8-11; Municipal Powers Act (Que), supra note 84, ss 2, 4, 6. MGA (Alta), supra note 82, s 9.

Supra note 25.

Ibid at para 13 .

Ibid at para 6 [citations omitted] [emphasis added]. 
and maintain opportunities for Maori to contribute to decision-making processes. ${ }^{117}$ For example, before making any "significant decision [relating] to land or a body of water," local authorities must take into account "the relationship of Māori and their culture and traditions with their ancestral land, water, sites, waahi tapu [sacred sites], valued flora and fauna, and other taonga [cultural treasure]." 118 Moreover, it is not enough for local authorities to maintain processes that will allow Maori to participate in making decisions; they must also consider ways in which they can "foster the development of Māori capacity to contribute to the decision-making processes of the local authority." 119

New Zealand law recognizes the need for Maori involvement in local government decision-making because those decisions matter to Maori rights and interests. In Canada, municipalities have changed from administrators of provincial policy to a form of devolved government, and they too should use their broad authority to govern in a manner consistent with the honour of the Crown and respect for the rights and jurisdiction of Canada's Indigenous peoples.

\section{LOCAL GovernMENTS AND THE CROWN's DUTY}

It is not controversial that federal, provincial, and territorial governments are bound by the duty to consult, which arises from the non-delegable principle of the honour of the Crown. In this section it is argued that municipalities are also bound by this duty. Compelling legal, policy, and practical arguments support treating local governments as the Crown when it acts as the Crown. In the alternative, if the honour of the Crown does not apply to municipalities directly, then they should generally be considered express or implied delegates of the Crown for the purposes of complying with the Crown's duty to consult.

\section{A. THE LAW}

\section{Must Municipalities Uphold the Honour of THE CROWN?}

Canadian municipalities are not "the Crown" in the same sense as provinces or the federal government, but the legal concept of "the Crown" is not one-dimensional. The role and ambit of the Crown in Canada is contextual and has changed over time.

It is not proposed that it would make sense to speak of, say, "The Queen in right of the City of Salmon Arm." Neither is it appropriate, at least not yet, to speak of "The Queen in right of the Yukon." ${ }^{120}$ Yet courts have taken for granted that the duty to consult applies to

Local Government Act 2002 (NZ), 2002/84, s 4 and Parts 2, 6 (see especially ss 75, 77, 81-82A); Resource Management Act 1991 (NZ), 1991/69, especially ss 6(e), 7(a), 8, 35A, 36A-36E, 42, 58M-58U, 59-80A. For an overview, see Local Government New Zealand, Frequently Asked Questions on Council-Māori Engagement: A Resource to Support Councils (October 2007), online: $<$ www.lgnz.co.nz/ assets/Uploads/Our-work/CME-FAQs-Maori.pdf $>$. Local Government Act 2002 (NZ), ibid, s 77(1)(c).

Ibid, s 81(1)(b).

Territorial governments do not have "Crown status," nor Crown prerogatives. See Paul Lordon, Crown Law (Toronto: Butterworths, 1991) at 11. The Yukon Territory, for example, was created by The Yukon Territory Act (UK), 61 Vict, c 6, and today its powers are determined by the Yukon Act, SC 2002, c 7. Section 18 delegates legislative powers to the Legislature of the Yukon. The preamble recognizes Yukon as "a territory that has a system of responsible government that is similar in principle to that of Canada," but the Yukon is not explicitly made an agent of the Crown. On the lack of constitutional status of the 
territorial governments, even though territorial governments are also a form of delegated government and lack a constitutional source of authority. ${ }^{121}$

It is not controversial that, for some purposes, the law will treat a municipality as a manifestation of the Crown. For example, a city or other local government can be viewed as an agent of the Crown when administering provincial policy. Unlike a private corporation, a municipal corporation can sometimes benefit from immunity from liability rooted in the doctrine of sovereign immunity. ${ }^{122}$ Courts also treat local governments as equivalent to the provincial and federal Crown for purposes of the application of the Canadian Charter of Rights and Freedoms. ${ }^{123}$ For purposes related to the duty to consult and accommodate, municipal actions will likely be attributed to the Crown because the Supreme Court has indicated that a broad interpretation of "the Crown" is appropriate in this context.

\section{a.}

\section{A Broad View of "the Crown"}

The term "Crown" lacks a consistent definition, and modern local governments readily come under the wider sense of the term. According to Peter W. Hogg's seminal work on constitutional law, for historical and constitutional reasons, the Canadian State, or government, is commonly referred to as "the Crown." 124 The "Crown" is used as "a convenient symbol for the State," such as when we refer to the Crown expropriating a house. ${ }^{125}$ In ordinary usage, "the State" or "the government" could be used instead of "the Crown." 126 When considering the meaning of "Crown" in the context of the duty to consult and how it applied to the National Energy Board (NEB), an administrative tribunal, the Supreme Court observed:

\footnotetext{
In one sense, the "Crown" refers to the personification in Her Majesty of the Canadian state in exercising the prerogatives and privileges reserved to it. The Crown also ... denotes the sovereign in the exercise of her formal legislative role ... and as the head of executive authority.... For this reason, the term 'Crown' is commonly used to symbolize and denote executive power. ${ }^{127}$
}

Yukon: see Steven Smyth, "Constitutional Development in the Yukon Territory: Perspectives on the 'Epp Letter'” (1999) 52:1 Arctic 71. The 2011 election platform of the Yukon Party included a promise to seek an amendment to the Yukon Act to include recognition of "the Crown in right of Yukon" and a transfer of ownership of lands and resources to the Territory. See Yukon Party, "Moving Forward Together" (2011) at 25.

121 See e.g. Ross River Dena Council v Yukon, 2012 YKCA 14, 358 DLR (4th) 100 [Ross River Dena] (the Yukon Territory's legislative scheme governing the staking of mineral claims did not meet the Territory's consultation requirements for rights claims asserted by the Ross River Dena, who had not entered into a treaty with the governments of Yukon or Canada); Little Salmon, supra note 41 at para 38 (the Yukon Territory's duty to consult was grounded in the honour of the Crown and applied independently of the treaty between the parties); Enge v Mandeville, 2013 NWTSC 33, [2013] 8 WWR 562 (the Government of the Northwest Territories (GNWT) breached its duty to consult; the Respondents conceded that the GNWT was "the proper Crown" to be brought as Respondent in the judicial review (ibid at para 21$)$ ). See the text accompanying notes 176-83.

Part I of the Constitution Act, 1982, being Schedule B to the Canada Act 1982 (UK), 1982, c 11 [Charter]. See also the text accompanying notes 162-70. Peter W Hogg, Constitutional Law of Canada, 5th ed (Toronto: Carswell, 2007) (loose-leaf), ch 10 at 10-2.

Ibid.

Ibid.

Clyde River, supra note 7 at para 28 [citations omitted]. 
The Supreme Court concluded that "[b]y this understanding, the NEB is not, strictly speaking, "the Crown." "128 However, as a statutory body with responsibility to make final decisions on activities related to exploration and exploitation of oil and gas resources, it acts on behalf of the Crown when deciding whether to approve a project, because "once it is accepted that a regulatory agency exists to exercise executive power as authorized by legislatures, any distinction between its actions and Crown action quickly falls away."129 Accordingly, and recalling the interchangeable references to "government action" and "Crown conduct" in Carrier Sekani, the Supreme Court described the NEB as "the vehicle through which the Crown acts."

The analogy of a vehicle for Crown action is even stronger for municipalities, because the powers legislatures have delegated to municipalities go beyond executive powers of the type delegated to the NEB and include quintessential governmental powers to legislate for governmental purposes, ${ }^{131}$ including, incidentally, the power to expropriate. ${ }^{132}$ Even more than for the NEB, as the Supreme Court put it, "any distinction between its actions and Crown action quickly falls away." 133

According to Hogg, for most purposes, the idea of the Crown being "one and indivisible" is misleading. ${ }^{134}$ Kent McNeil has shown how, from the late nineteenth century until the late twentieth century, courts moved away from the theory of the unity of the Crown, ${ }^{135}$ until the Supreme Court's surprising return to the concept of the Crown as indivisible in Grassy Narrows. ${ }^{136}$ The Supreme Court ruled Ontario had authority to "take up" tracts of land so as to limit hunting rights under Treaty 3, even though the treaty had been signed by treaty commissioners acting on behalf of the Dominion of Canada. ${ }^{137}$

McNeil has argued that " $[\mathrm{t}]$ he unified Crown is an abstraction ... that outlived its purpose as a juristic entity long ago." $138 \mathrm{He}$ acknowledged that one can still refer to "the Crown" in general terms, such as when referring to the honour of the Crown or the Crown's fiduciary duty, but this is not a reference to "a single juristic entity" but rather "in these contexts the term [Crown] encompasses the Crown in all its ... manifestations in Canada."

Support for a broad conception of the Crown is also found in $R$. v. Secretary of State for Foreign and Commonwealth Affairs, ex parte Indian Association of Alberta, ${ }^{140}$ another case that dealt with the issue of unity of the Crown in relation to the Crown's relationship with Aboriginal peoples. This case was brought to challenge the patriation of the Constitution in

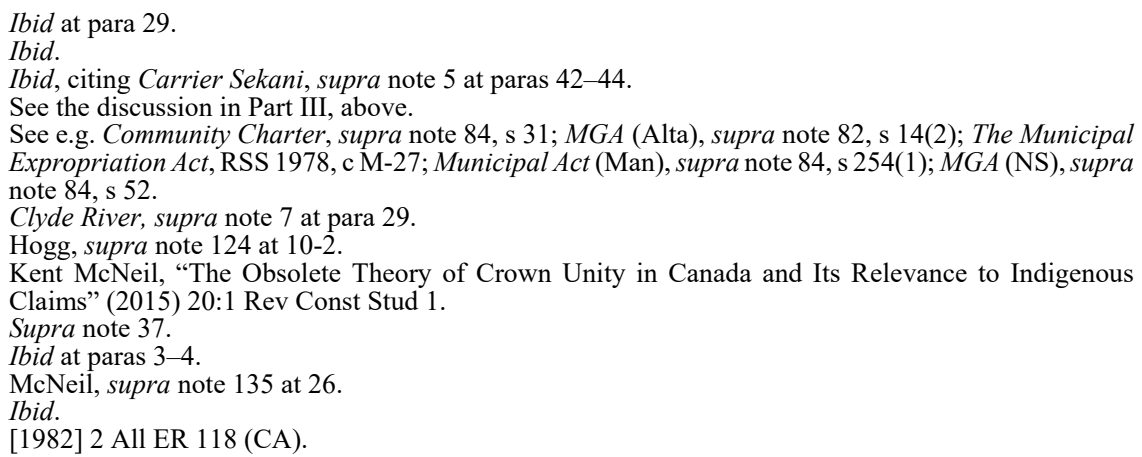


1982 on the grounds that it would interfere with treaty and other obligations the Queen of the United Kingdom owed to the Aboriginal peoples of Canada. The challenge was dismissed on the grounds that although at one time the Crown was one and indivisible, this was no longer the case. All three of the Lord Justices agreed that this change came, as Lord Denning put it, "not by statute, but by constitutional usage and practice." 141 Of particular interest for this discussion are comments by a majority of the Court that rights and obligations of the Crown can devolve to a government that is not independent and that the degree of devolution will depend on the extent of the power devolved. According to Lord Justice Kerr, the Crown's rights and obligations rest

\footnotetext{
with the overseas governments within the realm of the Crown, and not with the Crown in right or respect of the United Kingdom, even though the powers of such governments fall a very long way below the level of independence. Indeed, independence, or the degree of independence, is wholly irrelevant to the issue, because it is clear that rights and obligations of the Crown will arise exclusively in right or respect of any government outside the bounds of the United Kingdom as soon as it can be seen that there is an established government of the Crown in the overseas territory in question. In relation to Canada this had clearly happened by $1867 .^{142}$
}

Lord Justice May also saw the rights and obligations of the Crown devolve gradually and according to the degree of self-government granted:

[A]s different territories ... acquired the right to legislate on some and ultimately all matters within and affecting that territory, and thus to raise the finance to enable them to manage their own affairs, so pro tanto did any rights or obligations of what had been the Imperial Crown, that is to say the Crown in right of the United Kingdom, devolve on the Crown in right of the particular territory concerned. ${ }^{143}$

Just as the rights and obligations of the Crown in right of the United Kingdom could gradually pass to colonial governments to the extent that the latter were granted a degree of self-government, the rights and obligations of the Crown in right of a province pass to a municipal government, since the purpose is also to grant a degree of self-government to persons in a particular territory.

Regardless of whether the Crown is divisible or unified, including municipalities within the government's obligation to uphold the honour of the Crown is consistent with the generous and purposive approach the Supreme Court has taken to both the honour of "the Crown" and the duty to consult. ${ }^{144}$ It is also consistent with the Supreme Court's broad interpretation of the Crown in Grassy Narrows, which was evident from its description of the parties to Treaty 3, as "the Crown - a concept that includes all government power and the Ojibway." 145 Municipalities exercise devolved government power, and their purpose is to use that power for the public good. As Ann MacDonald explained, "[o]nce elected ... the [municipal] council is entrusted with responsibility for governing, not just in the interest

See Haida Nation, supra note 33 at para 17; Taku River, supra note 61 at para 24 (honour of the Crown); and see Carrier Sekani, supra note 5 at paras 43, 46; Taku River, ibid at para 24 (duty to consult). Supra note 37 at para 39. 
of those who elected them, but in the interest of the community generally, that is, in the public interest." 146

The question of whether the Crown includes local governments in Canada so as to bind them to uphold the honour of the Crown in dealing with Aboriginal peoples is analogous to the question of whether local governments in New Zealand are bound by the Queen's obligations in the Treaty of Waitangi:

[I]t would stretch credibility to argue that the only Treaty partner with obligations to Maori is the Queen because the New Zealand government did not sign the Treaty. However, the devolution of kawanatanga [sovereignty or governance] did not end at the central government level, although many argue that the devolution of Treaty obligations did. As provincial and local government[s] were established, these new units of government took on greater authority... The question is whether these local levels of government also inherited Treaty obligations, as settler government had inherited these from the original Treaty partner. Or, is there an arbitrary point at which kawan[a]tanga continues to flow down, but the concomitant Treaty obligations to Maori do not? ${ }^{147}$

Similarly, it can be asked why, as government is devolved to the local level in Canada, the honour of the Crown would not bind local governments. The honour of the Crown has been recognized as a constitutional principle in its own right, as well as a corollary of section 35 of the Constitution Act, 1982. ${ }^{148}$ The honour of the Crown is rooted in the Crown's pledge to protect Aboriginal peoples from exploitation, and applies to all dealings between the Crown and Aboriginal peoples. ${ }^{149}$ This protection of rights from the power of the state is analogous to the protection granted by the Charter, ${ }^{150}$ as the Indian Band argued unsuccessfully in Neskonlith. The Court of Appeal reproduced some of this argument ${ }^{151}$ but gave no reason for rejecting it. In the Court below, Justice Leask rejected the analogy as unpersuasive because it was not supported by precedent and because "[ $\mathrm{t}$ ] he Charter exists to protect individuals from governmental action" while "[s]ection 35 ... exists to protect the 'existing aboriginal and treaty rights' of the aboriginal peoples of Canada." ${ }^{152} \mathrm{He}$ concluded it would be "surprising" if this resulted in parallel interpretations. ${ }^{153}$

The Courts in Neskonlith did not have the benefit of the Supreme Court's recent decisions in Clyde River ${ }^{154}$ and Chippewas of the Thames, ${ }^{155}$ which considered the application of the duty to consult to the NEB. The Supreme Court held that the decisions of administrative

Ann McDonald, "In the Public Interest: Judicial Review of Local Government” (1983) 9:1 Queen's LJ 62 at 100 [emphasis in original].

New Zealand, Crown Forestry Rental Trust, The Treaty Challenge: Local Government and Maori, by Janine Hayward (2002) at 5, online: <https://www.boprc.govt.nz/media/32503/Maori-200829-TheTreaty ChallengeHaywardReport.pdf $>$.

Little Salmon, supra note 41 at para 42; Haida Nation, supra note 33 at para 20.

Little Salmon, ibid; Haida Nation, ibid at para 17; Manitoba Metis, supra note 42 at paras 68-69. See also the discussion in Part II, above.

Supra note 123.

Neskonlith, supra note 3 at para 62.

Neskonlith BCSC, supra note 3 at para 57. On the analogy between the application of the duty to consult to municipalities and the application of the Charter, see Promislow, supra note 31 at 68-69; Imai \& Stacey, supra note 31 at $296-98$.

Neskonlith BCSC, ibid.

Supra note 7.

Supra note 29. 
bodies must remain "within the contours of the state's constitutional obligations,"156 and therefore, final decisions of the NEB had to be consistent with section 35 of the Constitution Act, $1982 .{ }^{157}$ Since local governments are a vital part of how the state governs, it would be perverse to apply this obligation to administrative bodies but not to municipalities.

Neskonlith also predated Tsilhqot'in Nation v. British Columbia, ${ }^{158}$ in which the Supreme Court considered parallels between section 35 and the Charter when finding the doctrine of interjurisdictional immunity not relevant to whether provincial legislation applied to Aboriginal title lands. The Supreme Court found that Part I (the Charter) and Part II (the guarantee of Aboriginal rights, including section 35) of the Constitution Act, 1982 are "sister provisions." 159 Both operate "to limit governmental powers, whether federal or provincial," and the rights protected in each "are held against government — they operate to prohibit certain types of regulation which governments could otherwise impose."160

Courts have consistently found municipalities to be bound by the Charter, even though municipalities are not mentioned in section 32(1), while federal, provincial, and territorial governments are mentioned:

\section{2. (1) This Charter applies}

(a) to the Parliament and government of Canada in respect of all matters within the authority of Parliament including all matters relating to the Yukon Territory and Northwest Territories; and

(b) to the legislature and government of each province in respect of all matters within the authority of the legislature of each province. ${ }^{161}$

Although municipal actions have been tested for consistency with the Charter for as long as it has been in force, the Charter's application to municipalities was not expressly considered by the Supreme Court of Canada until Godbout v. Longueuil (City). ${ }^{162}$ All nine Justices found that requiring a municipal employee to live in the City contravened her right to privacy protected by the Quebec Charter of Human Rights and Freedoms, ${ }^{163}$ but only a minority considered whether section 7 of the Canadian Charter was also violated. Justice La Forest's reasons for the minority explained why the Charter applied to municipalities.

Justice La Forest found that municipalities perform governmental functions, are " matters within the authority' of the ... legislative body that created them," and are therefore included in section 32(1). ${ }^{164}$ They are governmental entities because they are democratically elected and accountable to their constituents, they have a general taxing power, and they are empowered to make laws and to administer and enforce those laws in a defined territory. Most importantly, provinces created municipalities to exercise powers that they would

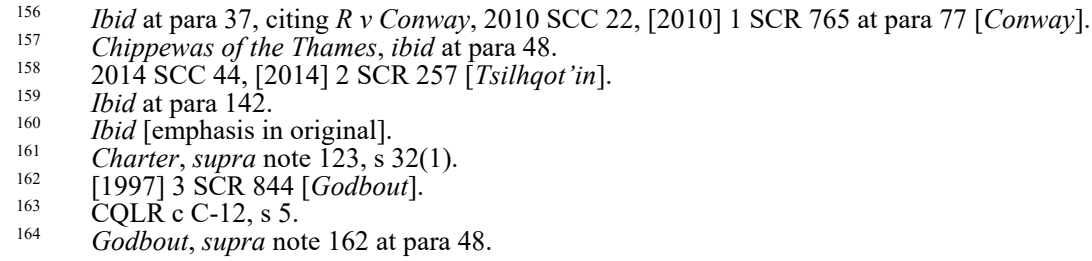


otherwise have to exercise directly. If the Charter did not apply to municipalities, the provinces could "simply avoid the application of the Charter by devolving powers on municipal bodies." 165

The governmental nature of municipalities distinguishes them from other bodies created by statute that merely perform some public functions and receive governmental funding, to whom the Charter does not apply, such as universities. ${ }^{166}$

The importance of not allowing governments to avoid the effects of the Charter also led Justice La Forest to reject the City's argument that the Charter did not apply because the residence requirement was a "private" and not a "governmental" act, as it resulted from a declaration required from the employee and had not been imposed by bylaw. Since all of a municipality's powers were derived from statute and were of a governmental character, the "particular modality a municipality [chose] to adopt [to advance] its policies [could not] shield [it] from Charter scrutiny.",167

The New Brunswick Court of Appeal adopted the reasoning of Justice La Forest in Charlebois $v$. Mowat et ville de Moncton. ${ }^{168}$ It concluded that a unilingual planning bylaw of the City of Moncton was contrary to the requirement in section 18(2) of the Charter of bilingual publication of "[t]he statutes, records and journals of the legislature of New Brunswick."169 A contrary interpretation would allow the New Brunswick legislature to evade these obligations. It would lead to planning regulations in areas outside municipalities where they are implemented directly by the province to be bilingual, while planning regulations inside municipalities would be implemented with unilingual bylaws. Such an interpretation of the application of the Charter would restrict its scope unduly, and would "allow governments to shirk their constitutional obligations." 170

Godbout and Charlebois stand for the principle that when provinces create governments to exercise provincial jurisdiction, they cannot delegate their constitutional powers stripped of their corresponding constitutional obligations. This is consistent with requiring administrative tribunals to operate within section 35 of the Charter in accordance with Chippewas of the Thames. All of this supports a requirement for the actions of municipalities to be consistent with section 35, including, in particular, the duty to consult and accommodate, which arises out of the principle of the honour of the Crown.

\section{b. A Narrow View of "the Crown"}

A focus on the corporate status of municipalities is more consistent with the traditional view of local governments as apolitical administrators of services. Such a government cannot

Ibid at paras 44-47. Justice La Forest contrasted previous decisions that had excluded universities from Charter scrutiny, including McKinney v University of Guelph, [1990] 3 SCR 229, from decisions that came to the opposite conclusion for certain colleges, such as Douglas/Kwantlen Faculty Assn v Douglas College, [1990] 3 SCR 570. He explained that the latter "were wholly controlled by government and were, in essence, emanations of the provincial legislatures that created them" (Godbout, ibid at para 47). Godbout, ibid at paras 55-56.

2001 NBCA 117, 242 NBR (2d) 259 [Charlebois].

Charter, supra note 123, s 18(2).

Charlebois, supra note 168 at para 109. 
itself be considered "the Crown." Even if municipalities are an order of government, a narrower understanding of "the Crown" sees the Crown not as encompassing all governmental power, but as more closely connected with the powers of the monarch, or the "personality of Her Majesty." This may be seen as a remnant of power being more connected to personal authority in the middle ages, compared to the modern idea of the state and its representation by the symbol of the Crown. ${ }^{171}$ This conception of the Crown carries with it such prerogative powers of the Crown as remain, such as making treaties and declaring war. ${ }^{172}$ While even the thought of such powers seems to sharpen any apparent disaccord with considering local governments as the Crown, they are not relevant to local authorities because prerogative powers cannot be invoked in support of executive activities by a government unless those activities are within its legislative authority. ${ }^{173}$

Courts and commentators drawing a bright line between local governments and the Crown see the Crown in this narrower sense. For example, Ian MacF. Rogers' classic and comprehensive work on municipal law states that a municipality has a distinct corporate identity and "is in no sense a representative of the Crown. That is, it represents no sovereignty distinct from the Crown, although it is, within its prescribed sphere, a political entity." 174 Similarly, Thomas Isaac concluded that municipalities do not represent or replace the Crown, and do not form any part of it. ${ }^{175}$ However, Rogers allows an exception to the general rule for the law enforcement functions of local governments. When carrying out those functions, local governments are delegates of the Crown and possess the immunities of the Crown. ${ }^{176}$

A narrow conception of the Crown does not preclude a municipality from acting as an agent of the Crown. However, this will be rare, since the local government will only be an agent of the Crown when performing duties imposed upon it by the provincial Crown. ${ }^{177}$ Both Isaac and Rogers support their claim that local governments are distinct from the Crown with cases that have found the municipality to be acting outside the agency relationship, and so not entitled to Crown immunities. For example, both cite Medicine Hat ${ }^{178}$ in support of the proposition that "a municipality is not immune from federal taxation" under section 125 of the Constitution Act, 1867, "which provides that no land of the federal or provincial Crown should be liable to taxation." ${ }^{179}$ As pointed out by the Court of Appeal, a municipality

See Martin Loughlin, "The State, the Crown and the Law" in Maurice Sunkin \& Sebastian Payne, eds, The Nature of the Crown (Oxford: Oxford University Press, 1999) 33, especially at 37, 41, 63.

Hogg, supra note 124 at 1-20; Lordon, supra note 120 at 61-106.

Lordon, ibid at 11.

Ian MacF Rogers, The Law of Canadian Municipal Corporations, 2nd ed, vol 1 (Toronto: Carswell, 2009) (loose-leaf release 8), § 2.1.

Thomas Isaac, Aboriginal Law: Commentary and Analysis (Saskatoon: Purich, 2012) at 332-33. In addition to City of Medicine Hat $v$ Attorney General of Canada (1984), 11 DLR (4th) 117 (Alta QB) [Medicine Hat], aff'd (1985), 18 DLR (4th) 428 (Alta CA) [Medicine Hat CA], leave to appeal to SCC refused, 39 Alta LR (2d) xliv, Isaac also cites Hoddinott v Nickerson and Underhill (1983), 46 NBR (2d) 340 (QB) [Hoddinott] (the Provincial Minister and Municipal Electoral Officer have no statutory authority to decide that council exceeded its jurisdiction when it ordered a plebiscite on a particular question) and Bower v Richardson Construction Co Ltd, [1938] OR 180 (CA) (a contract with the municipality to build a bridge was not enough to enable the defendant company to avail itself of the defence of statutory authority for damage done to the plaintiff's house).

Rogers, supra note 174, $\$ 2.1$, citing Pon Yin v Edmonton (1915), 8 WWR 809 (Alta SC(TD)).

Rogers, ibid, citing Medicine Hat, supra note 175 (when executing a public work, the municipality was not in the same position as the Crown).

Supra note 175.

Rogers, supra note $174, \S 2.1$. 
will only qualify as an agent of the Crown when it is an "instrumentality" of the Province because it is carrying out governmental activities that would otherwise have to be carried out by the Province, and according to the Province's policy rather than its own. ${ }^{180}$ The Province had not required the City to follow any particular policy regarding the municipality's production and distribution of gas, which was the subject matter of the taxation at issue. ${ }^{181}$ Accordingly, the City was not an agent of the Crown and could not avoid taxation.

Even when municipalities are not acting as Crown agents, courts have allowed them immunities not available to private parties. This has its roots in "sovereign immunity, which prevented the King from being sued." 182 Although the courts have narrowed these immunities to protect only the policy-making or governmental actions of municipalities, this shows that in some circumstances, courts treat local governments like the Crown and not like a private party. $^{183}$

\section{c. Conclusion: Local Governments and the Honour of the Crown}

As an "order of government," modern municipalities are part of the state and exercise governmental authority on behalf of the Crown. While municipalities come under a broad conceptualization of "the Crown," some cases have applied a narrower conception that excludes local governments except when acting as agents of the Crown. Courts have also allowed municipalities to benefit from some immunities otherwise only available to the Crown.

Municipalities have powers to tax, to expropriate, to legislate, and to engage the coercive power of the state, including applying a penalty of incarceration. They carry out governmental functions over a defined territory, and their mandate comes from representatives elected by the residents of that territory. They have all these governmental characteristics in common with their federal and provincial counterparts. Is the lack of a direct constitutional source for their authority material to whether they fall within the ambit of the "honour of the Crown"? To those who are subject to the exercise of governmental power, it is at most of academic interest whether that power has a direct or an indirect constitutional source. ${ }^{184}$ Their land is just as expropriated, or their hunting ground just as compromised, because a nearby lakeshore has been approved for subdivision.

A generous interpretation of the honour of the Crown will not leave its application dependent on whether a government has direct constitutional authority. A generous interpretation would take the Aboriginal perspective into account, as Chief Justice Dickson

Medicine Hat CA, supra note 175 at paras 18-21.

Ibid.

Makuch, Craik \& Leisk, supra note 23 at 115.

Ibid at 115-18, 122-29. See also Lordon, supra note 120 at 382-409.

A constitutional source of authority for Canadian municipalities is not inconceivable. It has been argued that local self-government should be considered an inherent right or a fundamental constitutional principle in a free and democratic society (see Magnusson, supra note 21). In the constitutional negotiations of the late 1970s, the Federation of Canadian Municipalities sought constitutional recognition of municipalities. See Canada, Parliamentary Information and Research Service, "Municipalities, the Constitution, and the Canadian Federal System," by Michael Dewing, William R Young \& Erin Tolley (Ottawa: Library of Parliament, 2006) at 9-12, online: <publications.gc.ca/ collections/Collection-R/LoPBdP/BP-e/bp276-1e.pdf>. 
did in Mitchell v. Peguis Indian Band ${ }^{185}$ when considering the meaning of the Crown in the context of section 90(1)(b) of the Indian Act ${ }^{186}$ which in some circumstances deems personal property purchased by "Her Majesty" to be situated on a reserve:

[T] he [A]boriginal understanding of "the Crown" or "Her Majesty" is rooted in pre-Confederation realities. The recent case of Guerin took as its fundamental premise the "unique character both of the Indians' interest in land and of their historical relationship with the Crown"... [T] [Te Indians' relationship with the Crown or sovereign has never depended on the particular representatives of the Crown involved. From the [A]boriginal perspective, any federal-provincial divisions that the Crown has imposed on itself are internal to itself and do not alter the basic structure of Sovereign-Indian relations. ${ }^{187}$

From the Aboriginal perspective, if governmental decisions may affect Aboriginal rights or interests, the duty to consult is best located with the decision-maker. ${ }^{188}$ This is no less true when that government is acting under delegated authority, because it is usually not possible for the delegating government to interfere with or withdraw that delegation in time to affect the decision. Even if municipalities are not, in the strictest sense, a manifestation or an agent of the Crown, they are, just like the NEB, a "vehicle through which the Crown acts"189 and therefore, must act in accordance with the Crown's constitutional obligations. ${ }^{190}$

A final reason for favouring a wide ambit of the honour of the Crown and the duty to consult tracks reasoning that supports the Charter's application to municipalities: otherwise provinces could delegate their constitutional powers to local governments free of constitutional restraints on those powers. In Grassy Narrows, the Supreme Court of Canada held that after a transfer of the beneficial ownership in lands from the federal government, Ontario could use its constitutional powers to take up those lands, but this was "subject to the Crown's duties to the Aboriginal peoples who had interests in the land."191 Although the transfer of authority from provinces to municipalities results from a different mechanism (a statutory delegation instead of a transfer of ownership of land), the same principle should apply - this transfer of authority does not lessen the Crown's duties to the Aboriginal peoples that are affected.

\section{ARE LOCAL GOVERNMENTS SUBJECT TO A DELEGATED Duty TO CONSUlt?}

If actions of local governments are not properly attributable to the Crown, local governments may still be made subject to the duty to consult by delegation. The honour of the Crown cannot be delegated, ${ }^{192}$ but legislatures may delegate the duty to consult to tribunals, and the existence and scope of the duty depends on the mandate conferred by the legislation. ${ }^{193}$ Like tribunals, local governments receive their authority by delegation, and the scope of that authority depends on the terms of the enabling legislation. These parallels in

[1990] 2 SCR 85 [Peguis Indian Band].

RSC 1985, c I-5.

Peguis Indian Band, supra note 185 at 108-109 [emphasis added by Dickson CJC].

Neskonlith, supra note 3 at para 64, quoting Factum of Neskonlith Indian Band at para 49.

Clyde River, supra note 7 at para 29.

Chippewas of the Thames, supra note 29 at paras 29, 37.

Supra note 37 at para 46.

See Haida Nation, supra note 33 at para 53.

Carrier Sekani, supra note 5 at paras 55-56. 
the legal foundation of tribunals and local governments mean that the duty to consult can also be delegated to local governments. ${ }^{194}$ As with tribunals, the existence and scope of the duty will depend on the legislation.

The diverse and usually narrow functions, purposes, and powers of tribunals led the Supreme Court to conclude that it is not possible to generalize about whether tribunals have been authorized to consult with Aboriginal peoples. Consultation is a constitutional process and may involve "facts, law, policy, and compromise" and therefore a tribunal seeking to consult must "possess remedial powers necessary to do what it is asked to do in connection with the consultation." 195 The Supreme Court held that whether express or implied authorization to fulfill the duty to consult exists will need to be determined by examining that tribunal's enabling statute and the legislative intent reflected in its provisions. ${ }^{196}$

Ultimately, the existence and scope of all municipal authority and duties, including the duty to consult, depends on the terms of the enabling legislation. Authority relating to the duty to consult is rarely dealt with in express terms, so usually the question will be whether a delegation of the duty is implicit. While the terms of the statute must prevail, the functions and powers of today's local governments warrant a presumption in favour of an implicit delegation of the duty to consult.

\section{a. Presuming a Delegation of the Duty to Consult}

There are two main reasons for presuming that municipal enabling legislation includes a delegation of the duty to consult. The first is that this legislation creates governments. One "critical difference" between municipalities and most other delegates of provincial powers is that municipal elections make them directly accountable to the electorate. ${ }^{197}$ In Part III, it was demonstrated that in the twenty-first century, local governments have achieved legislative and judicial recognition as an essential order of government in Canada's democracy. As governments, when exercising governmental powers, municipalities must be subject to governmental duties.

In Carrier Sekani, the Supreme Court held that consultation is a constitutional process that may involve "facts, law, policy, and compromise," and therefore requires remedial powers adequate to the task. ${ }^{198}$ Unlike most tribunals, local governments are created to be lawmakers, and therefore, they must regularly engage in the same kind of process described in Carrier Sekani. The Supreme Court recognized this in Catalyst Paper when it observed that municipal councillors fulfill a role that is legislative rather than adjudicative, and that bylaws are not quasi-judicial decisions because "they involve an array of social, economic, political and other non-legal considerations." "199 As described above, reforms to enabling legislation and greater judicial reluctance to interfere with the decisions of local governments have

In Neskonlith, supra note 3, the Indian Band did not argue that the duty had been delegated to the municipality (see ibid at paras 65-67), but both levels of court assumed that the analysis applied to tribunals in Carrier Sekani, supra note 5, could be applied to municipalities. See especially Neskonlith, ibid at para 65 and Neskonlith BCSC, supra note 3 at para 47.

Carrier Sekani, supra note 5 at para 60.

Ibid, citing Conway, supra note 156 at para 82.

Makuch, Craik \& Leisk, supra note 23 at 75.

Supra note 5 at para 60.

Supra note 81 at para 19 . For the full passage, see the text accompanying note 81 , above. 
broadened and strengthened municipal authority. This supports an expectation that municipalities have the capacity to consult, because making multi-faceted policy decisions is at the heart of the purpose of modern local governments.

Another reason for inferring that municipal enabling legislation includes a duty to consult flows from the principle that a provincial legislature can delegate no more than the powers it has under the Constitution. The Constitution Act, 1867, gives provinces exclusive authority to make laws related to municipal institutions. ${ }^{200}$ It has long been accepted that this section cannot be used to give municipalities greater powers than provinces have under other heads of jurisdiction under section 92. ${ }^{201}$ In Grassy Narrows, the Supreme Court held that Ontario has the power to take up lands under Treaty 3 without Canada's approval, but the exercise of this power is conditional on Ontario exercising its powers in conformity with the honour of the Crown. ${ }^{202}$ The Supreme Court elaborated that when the federal or provincial governments exercise Crown power, "the exercise of that power is burdened by the Crown obligations toward the Aboriginal people in question." ${ }^{203}$ Likewise, when provinces delegate Crown powers, courts should assume that they did this in conformity with the honour of the Crown, and so they did not delegate these powers free of accompanying obligations. Of course, a legislature could expressly provide that the duty to consult is not delegated and will not apply to the municipality. However, as the Supreme Court said in Carrier Sekani, the duty to consult is a constitutional duty and "[i]t must be met." 204 If the legislature has not delegated the duty and has not otherwise ensured that the duty will be met, then the legislation may be invalid, as considered further below.

Another way of reflecting on the need for provinces to act in accordance with the honour of the Crown when delegating powers to local governments is to consider that the powers granted to local governments are substantial, and generally make municipalities the dominant authority in the regulation of land use. ${ }^{205}$ The importance of powers of land use control to Aboriginal title claims was recognized by the Yukon Court of Appeal in Ross River Dena, when it stated that " $[\mathrm{t}]$ he honour of the Crown demands that it take into account Aboriginal claims before divesting itself of control over land." 206 Therefore, when delegating governmental powers it is incumbent on legislatures to consider that local governments may use those powers to infringe Aboriginal rights protected by section $35{ }^{207}$ If the legislation does not expressly address how this risk will be minimized and managed, finding an implicit delegation may save the legislation from invalidity due to a violation of the honour of the Crown.

Some local bodies, sometimes known as "special purpose bodies,"208 are recipients of delegated authority to perform specific functions in service of a locality, such as health,

Constitution Act, 1867, supra note 21, s 92(8).

Ontario (Attorney General) v Canada (Attorney General), [1896] AC 348 at 364 (PC). For a discussion of this case and how the division of powers under the Constitution Act limits municipal authority, see Makuch, Craik \& Leisk, supra note 23 at 132-37. Supra note 37 at para 50.

Ibid.

Supra note 5 at para 63. The Supreme Court reiterated this in Chippewas of the Thames, supra note 29 at para 32, and in Clyde River, supra note 7 at para 30.

See Hoehn, supra note 23, especially at 154-55; Makuch, Craik \& Leisk, supra note 23 at 159.

Ross River Dena, supra note 121 at para 38.

Constitution Act, 1982, supra note 4.

For a concise discussion of special purpose bodies, see Makuch, Craik \& Leisk, supra note 23 at 16-18. 
education, parks, and libraries. These bodies have narrow mandates, and are usually led by appointed rather than elected officials. These features make them more like statutory tribunals than governments, and therefore a presumption that the duty to consult applies would not be appropriate. Accordingly, the extent to which these bodies are subject to the duty to consult requires individual analysis beyond the scope of this discussion.

In summary, when courts discern legislative intent as to the scope and meaning of municipal enabling legislation, they do so in the context of limitations on the provincial power to delegate. Provinces cannot delegate powers they do not have, so they also cannot delegate governmental authority free of constitutional limitations on those powers. When a statute creating a subordinate government is silent on the matter, courts should presume that the legislature would not have created a subordinate government free of constitutional limitations and obligations that the legislature itself was subject to.

\section{b. The Content and Interpretation of Enabling Legislation}

\section{i. $\quad$ Explicit Requirements to Consult}

Express requirements to consult with Aboriginal governments are not common in municipal enabling statutes, ${ }^{209}$ though, as discussed below, they are becoming increasingly common in relation to municipal land use planning powers. An exceptional provision that could be read as a general requirement to consider Aboriginal rights in the exercise of all municipal powers is section 5 of the Charter Communities Act of the Northwest Territories: "For greater certainty, nothing in this Act shall be construed so as to abrogate or derogate from any existing aboriginal or treaty rights of the aboriginal peoples of Canada under section 35 of the Constitution Act, 1982."210 Since section 5 expressly prevents municipal powers from being used to interfere with section 35 rights, it invites municipalities to consult with and accommodate Indigenous peoples to ensure that their decisions do not have this effect.

In the few instances that express requirements to consult appear in municipal enabling legislation, they mainly relate to delegated land use regulation powers, and this is likely because the potential for interference with Aboriginal rights is most obvious in this realm. The most important decision made by municipalities in this sphere is usually the adoption or amendment of a land use plan, as this document sets out policies that determine the use of more specific forms of land use regulation, such as zoning.

Though not directly applicable to municipalities, some provisions of the Municipal Act (YT), supra note 84 recognize the relevance of municipal powers to Aboriginal rights. The Act requires the Yukon Municipal Board or the Minister, as applicable, to consult with each nearby Yukon First Nation government before determining any proposal to form, dissolve, or alter the boundaries of a municipality, or to form a rural government structure: see ibid, ss 17-22, 27-32. Similarly, the Charter Communities Act, SNWT 2003, c 22, s 8(1)(a) being Schedule A to the Municipal Statutes Replacement Act, SNWT 2003, c 22 [Charter Communities Act (NWT)] requires the Minister to consult with a band council or other local Aboriginal organization before establishing a charter community. 
Names for municipal land use plans vary, and include "official community plan," "municipal development plan," and "municipal planning strategy." "211 Because of their high place in the planning hierarchy, these plans are sometimes referred to as "quasiconstitutional" documents. ${ }^{212}$ Once in place, these plans have long-term and often irreversible consequences, since they govern zoning and other regulations that determine how land will be used and developed, ${ }^{213}$ and in most jurisdictions, bylaws and developments must be consistent with plans. ${ }^{214}$ Accordingly, legislatures have universally recognized the importance of requiring local governments to allow public participation and consultation with affected persons in the development of plans. ${ }^{215}$

In addition to general public participation requirements, some provinces have policies and statutory provisions mandating consultation if Aboriginal rights may be affected by land use control powers. In British Columbia, this is required for the development of plans, and Alberta will follow suit when an amendment to section 636 of its Municipal Government Act is proclaimed in force. ${ }^{216}$ In Ontario, First Nations are included in the definition of "public body" and this brings them within the ambit of numerous provisions related to notice and consultation in the Planning Act (Ont), including the development of official plans. ${ }^{217}$

In Saskatchewan and Ontario, legally binding provincial policies mandate consultation by municipalities. The position of Ontario's Ministry of Municipal Affairs and Housing is that

See e.g. LGA 2015 (BC), supra note 84, s 471; Municipal Act (YT), supra note 84; The Planning and Development Act, 2007, SS 2007, c P-13.2, s 29 [PDA (Sask)], “official community plan"; Planning Act, RSO 1990, c P.13 [Planning Act (Ont)]; Planning Act, RSPEI 1988, c P-8 [Planning Act (PEI)], "official plan"; The Planning Act, SM 2005, c 30, s 40 [Planning Act (Man)] "development plan"; MGA (Alta), supra note 82, "municipal development plan"; Community Planning Act, RSNB 1973, c C-12 [CPA (NB)] "municipal plan" or "basic planning statement"; $M G A(\mathrm{NS})$, supra note 84, "municipal planning strategy." Plans fulfilling the same or similar functions are sometimes enacted on a regional basis: see e.g. MGA (Alta), ibid, s 631 ("intermunicipal plan"); Alberta Land Stewardship Act, SA 2009, c A-26.8 ("regional plan"); Planning Act (Ont), ibid, s 27 (lower-tier municipalities must amend official plans to conform with the official plan of the upper-tier municipality).

212 Old St Boniface Residents Assn Inc v Winnipeg (City), [1990] 3 SCR 1170 at 1207-208, La Forest J, dissenting. On a plan as a quasi-constitutional document, see also Ruth Sullivan, Sullivan and Driedger on the Construction of Statutes, 4th ed (Markham: Butterworths Canada, 2002) at 380-81; Makuch, Craik \& Leisk, supra note 23 at 175-78; Hoehn, supra note 23 at 136-40.

213 See e.g. LGA 2015 (BC), supra note 84, s 471(1) ("[a]n official community plan is a statement of objectives and policies to guide decisions on planning and land use management"); MGA (NS), supra note 84, s 213 ("to provide statements of policy to guide the development and management of the municipality"); PDA (Sask), supra note 211, s 31 ("to provide a comprehensive policy framework to guide the physical, environmental, economic, social and cultural development of the municipality"). See e.g. LGA 2015 (BC), ibid, s 478(2) (bylaws must be consistent); Municipal Act (YT), supra note 84, s 284 (provisions of a plan supersede conflicting zoning bylaw) and ss 283(1)-(2) (conflicting developments prohibited); Planning Act (Ont), supra note 211, s 24; PDA (Sask), ibid, s 34(2) (inconsistent zoning bylaw is invalid) and s 40(1) (conflicting developments prohibited); $M G A$ (NS), supra note 84, s 219(3) (land use bylaw must carry out intent of municipal planning strategy); Planning Act (PEI), supra note 211, s 15(2) (bylaws must be consistent); CPA (NB), supra note 211, s 27.1 (municipal plan prevails if conflict with zoning or subdivision bylaw).

See e.g. LGA 2015 (BC), ibid, ss 475, 477(3)(c); Municipal Act (YT), ibid, ss 280-81; Planning Act (Man), supra note 211, ss 46, 168; PDA (Sask), ibid, ss 24, 35, 207-208, 210-11; MGA (Alta), supra note 82, ss 230, 606, 636, 692; Planning Act (Ont), ibid, ss 17(15)-(21); CPA (NB), ibid, ss 25, 31, 68; MGA (NS), supra note 84, ss 204-206; Planning Act (PEI), ibid, s 11.

$L G A 2015$ (BC), ibid, s 434(2)(c) (development of a regional growth strategy requires consultation with First Nations) and s 475(2)(iv) (development of official community plan requires consideration of consultation with First Nations); Bill 8, An Act to Strengthen Municipal Government, 3rd Sess, 29th Leg, Alberta, 2017, cl 1(56) (assented to 7 June 2017). (adjacent Indian reserves and adjacent Metis settlements must be notified when preparing a municipal development plan).

217 Planning Act (Ont), supra note 211, s 1(1), "public body." See also, among others, ss 17(15), 21(1), 26(3), 34(15), 51.1(2.2)(b). 
"municipalities have a duty to consult in some circumstances." 218 The Province has given this directive the force of law by using section 3 of the Planning Act (Ont) ${ }^{219}$ to adopt a formal policy statement binding on municipalities and all other bodies when making planning decisions. $^{220}$

Similarly, in Saskatchewan, the Province's official consultation policy provides that:

Municipalities may have a duty to consult whenever they independently exercise their legal authority in a way that might adversely impact the exercise of Treaty and Aboriginal rights and/or traditional uses on unoccupied Crown land or other lands to which First Nations and Métis have a right of access. ${ }^{221}$

Saskatchewan's Planning and Development Act, $2007^{222}$ provides for regulations adopting provincial land use policies and statements of provincial interest, and plans and bylaws adopted under the Act must be consistent with these policies. ${ }^{223}$ The Statements of Provincial Interest Regulations ${ }^{224}$ establishes "cooperative planning" as a planning principle, and envisages municipalities, First Nations and Metis people, and others working together. ${ }^{225}$ Moreover, one of the Province's statements of interest calls for enhancing the participation of First Nations and Metis communities in land use planning and development policies. This should be done, "insofar as is practical" by, among other things, encouraging "engagement with First Nations and Métis communities ... where there is a common interest" and minimizing, mitigating, or avoiding impacts on hunting, fishing, and trapping on unoccupied Crown land. ${ }^{226}$

To date, Nova Scotia has not expressly imposed any statutory or regulatory obligation for local governments to consult with Aboriginal governments. However, one provincial policy document encourages "meaningful consultation with the Mi'kmaq on decisions that impact land and natural resources." 227 The document includes municipalities in a broad grouping of public and private actors it calls "proponents," which also includes government departments, private industry, and consulting firms. ${ }^{228}$ The Province's position is that it retains the ultimate responsibility for consultation, but that municipalities, like other proponents, will "engage" the Mi'kmaq in a consultation process when appropriate. ${ }^{229}$

Ontario, "Case Studies," supra note 10 at 1.

Supra note 211.

Ontario, Ministry of Municipal Affairs and Housing, "2014 Provincial Policy Statement Under the Planning Act" (Toronto: Queen's Printer for Ontario, 2014), online: <www.mah.gov.on.ca/AssetFactory. aspx? did $=10463>$.

Government of Saskatchewan, "First Nation and Métis Consultation Policy Framework" (June 2010) at 8 , online: $<$ https://www.saskatchewan.ca/residents/first-nations-citizens/duty-to-consult-first-nationsand-metis-communities\#duty-to-consult>.

Supra note 211.

Ibid, ss 7-8.

RRS, c P-13.2, Reg 3.

Ibid, Appendix, para 3.6.

Ibid, Appendix, para 6.3.

Nova Scotia, Office of Aboriginal Affairs, "Proponents' Guide: The Role of Proponents in Crown Consultation With the Mi'kmaq of Nova Scotia," 2nd revision (November 2012) at 1, online: <https:// www.novascotia.ca/nse/ea/docs/ea-proponents-guide-to-mikmaq-consultation.pdf>.

Ibid.

Ibid at 2 


\section{ii. $\quad$ Implicit Requirements to Consult}

When provincial enabling statutes include some express requirements to consult, it might be possible to mount an argument against presuming a duty to consult where those express requirements do not apply, based on the expressio unius est exclusio alterius maxim (to express one thing is to exclude another) ${ }^{230}$ In other words, since some municipal enabling statutes make the exercise of certain powers dependent on consultation with First Nations, it might be arguable that, at least in those statutes, municipalities are by implication excluded from having to consult before exercising any other powers, even if Aboriginal rights may be affected.

Applying the expressio unius maxim to exclude municipalities from the duty to consult would be perilous. This conclusion relies on an inference that the legislature intended this exclusion. However, commentators and courts have observed that this maxim should be applied with caution and must yield to indications that the exclusion may not reflect legislative intent. ${ }^{231}$ Moreover, such an inference, without more, would be inconsistent with the modern principle of statutory interpretation. According to the Supreme Court, "statutory interpretation cannot be founded on the wording of the legislation alone. ${ }^{, 232}$ Instead, today's approach is to read the words in their "entire context and in their grammatical and ordinary sense harmoniously with the scheme of the Act, the object of the Act, and the intention of Parliament."233

Municipalities are democratic governments with flexible powers over a range of matters that fall under provincial jurisdiction. In view of the importance of consultation in furthering reconciliation, it is difficult to conceive of why a province would want to preclude municipalities from consulting with Aboriginal peoples on any matter that affects them. The Saskatchewan Court of Appeal refused to apply the expressio unius maxim when the result — preventing courts from making certain types of interim orders - would have conflicted with provisions intended to protect the interests of children of divorced parents. ${ }^{234}$ The Court said that to suppose this result was intended "is to expect implication to carry the burden of that intention. This is a lot to expect. ${ }^{, 235}$ Those words are just as applicable to the duty to consult.

As suggested above, a factor favouring an implied delegated duty to consult when the municipal enabling statute is silent is that the contrary interpretation may place the constitutionality of the statute in jeopardy. Statutes are presumed to comply with constitutional limitations and norms. ${ }^{236}$ The honour of the Crown has been recognized as a "constitutional principle," 237 and it follows that when a province delegates powers, it would

Dorval v Dorval, 2006 SKCA 21, 264 DLR (4th) 512 at para 10 [Dorval].

See e.g. ibid at paras 13-20; Sullivan, supra note 212 at 192-93. See also Stéphane Beaulac, Handbook on Statutory Interpretation: General Methodology, Canadian Charter and International Law (Markham: LexisNexis Canada, 2008) at 238-39.

Rizzo \& Rizzo Shoes Ltd (Re), [1998] 1 SCR 27 at para 21.

Ibid, citing EA Driedger, Construction of Statutes, 2nd ed (Toronto: Butterworths, 1983) at 87.

Dorval, supra note 230 at paras $10-22$.

Ibid at para 17.

Sullivan, supra note 212 at $366-67$.

Manitoba Metis, supra note 42 at para 69, citing Little Salmon, supra note 41. 
presumably do so in a manner consistent with fulfilling the province's duties that flow from this constitutional principle.

In addition to constitutional law, international law also influences how statutes are read. The modern principle of statutory interpretation calls on courts to read the words of the Act "in their entire context" - a context which includes the values reflected in international law. ${ }^{238}$ Particularly important in this context is the United Nations Declaration on the Rights of Indigenous Peoples, ${ }^{239}$ which the Truth and Reconciliation Commission (TRC) adopted as a framework for reconciliation. The TRC called on federal, provincial, and municipal governments to fully adopt and implement the Declaration as a framework for reconciliation, and called on the federal government to develop a national plan to achieve the goals of the Declaration. ${ }^{240}$ Relevant to the subject of this article are the Declaration's articles relating to the rights of Indigenous peoples to their lands, especially Article 19, which requires states to "consult and cooperate in good faith with the [I]ndigenous peoples concerned ... to obtain their free, prior and informed consent before adopting and implementing legislative or administrative measures that may affect them." 241

To comply with the Declaration, provinces transferring powers over land use to local governments must ensure that they comply with Article 19. This is because "prior" consent means that consultation occurs before the activity begins and far enough in advance to allow for effective consultation or consensus processes, "informed" includes a requirement of timely and adequate information, and "consent" is a process that includes participation and consultation. ${ }^{242}$ Article 19 can only be complied with if the duty to consult binds the government that undertakes the legislative or administrative measures. Once decisions affecting the rights of Aboriginal peoples have been made without consultation, the availability of subsequent recourse to courts or provincial authorities will not be enough, because it will not be possible to fix the flaws in the initial process retroactively.

Any doubt about whether municipal enabling legislation confers authority to consult on local governments should favour an interpretation that the authority exists. Janna Promislow has pointed out that if no duty to consult applies to a municipal decision that is final, then the remedy has been denied and the legislation may be unconstitutional. ${ }^{243}$ She noted that a

Baker v Canada (Minister of Citizenship and Immigration), [1999] 2 SCR 817 at para 70, citing Ruth Sullivan, Driedger on the Construction of Statutes, 3rd ed (Markham: Butterworths Canada, 1994) at 330; Sullivan, supra note 212 at 262; Beaulac, supra note 231 at 396-406.

Supra note 2. The TRC observed that Canada initially refused to adopt the Declaration because, among other things, it objected to provisions dealing with lands and resources (TRC vol 6, supra note 1 at 26). In 2010, Canada endorsed the Declaration as a "non-legally binding" and "aspirational" document (Aboriginal Affairs and Northern Development Canada, "Canada's Statement of Support on the United Nations Declaration on the Rights of Indigenous Peoples" (12 November 2010), online: <www.aadncaandc.gc.ca/eng/1309374239861/1309374546142>. TRC vol 6, ibid at 28-29 (calls to action 43 and 44).

UNDRIP, supra note 2. See also, among others, arts 18, 26-27, 32, which provide that Indigenous peoples have rights to their traditional lands and to plan for the use and development of those lands, a right to be consulted about any project affecting their lands, a right to an independent process to adjudicate rights of Indigenous peoples to their land, and a right to participate in this process.

Mauro Barelli, "Free, Prior and Informed Consent in the Aftermath of the UN Declaration on the Rights of Indigenous Peoples: Developments and Challenges Ahead" (2012) 16:1 Intl JHR 1 at 2, citing Permanent Forum on Indigenous Issues, Report of the International Workshop on Methodologies Regarding Free, Prior and Informed Consent and Indigenous Peoples, UNESC, 4th Sess, UN Doc E/C.19/2005/3.

Supra note 31 at 74. 
recent decision of the Yukon Court of Appeal upheld the validity of a statute governing quartz mining claims because the Act allowed areas to be excluded from quartz mining claims if exploration would prejudice claimed Aboriginal rights. ${ }^{244}$ Promislow observed that the Court commented that "[s]tatutory regimes that do not allow for consultation and fail to provide any other equally effective means to acknowledge and accommodate Aboriginal claims are defective and cannot be allowed to subsist."245

\section{B. Practical and Policy Grounds}

Several policy reasons support holding municipalities to a duty to consult. First, local governments are often in the best position to consult. Municipal governments typically have powers to determine permissible land uses, including determining the location and density of development, and have authority to make other decisions that may affect Aboriginal and treaty rights. The courts have already recognized that "[1] and use decisions often give rise to a duty to consult," ${ }^{246}$ because they are "often ... strategic, higher level decision[s]." ${ }^{247}$ In Part III above, it was demonstrated that in Spraytech, the Supreme Court endorsed the principle of subsidiarity, which recognizes the value of local government when it is "closest to the citizens affected" and so able to be "most responsive to their needs ... and to population diversity." ${ }^{248}$ The Neskonlith Indian Band's argument that local governments are "located in the area where the proposed development [would] take place and have a better understanding of the local circumstances than centralized governments" was consistent with this principle. ${ }^{249}$

Local governments can contribute to reconciliation by addressing small differences early before they escalate. Arthur Pape explains that the goal of reconciliation "could be undermined 'on the ground' by a myriad [of local] government decisions that adversely affect - for a very long time - the potential to exercise Aboriginal peoples' s. 35 rights that depend on the use and occupation of their territorial lands and resources." ${ }^{250}$ Failing to address Indigenous concerns early can be costly and can erode relationships. As discussed above, some of the most violent and damaging confrontations involving Indigenous peoples in Canada, including Oka and Caledonia, have been triggered by local decisions. The best way to prevent the escalation of a conflict is early consultation. Industry experts have acknowledged that "[t]ime and time again, it has been unfortunately demonstrated that neglecting to appropriately address the concerns of Aboriginal people in the early stages of the planning process (or at all) can lead to severe and negative consequences, both socially and economically." 251

Ibid, referring to Ross River Dena, supra note 121 which considered the Quartz Mining Act, SY 2003, c $14, \mathrm{~s} 15$.

Promislow, supra note 31 at 74, citing Ross River Dena, ibid at para 37.

Squamish Nation v British Columbia (Community, Sport and Cultural Development), 2014 BCSC 991, [2014] 8 WWR 742 at para 147 [Squamish Nation], citing Haida Nation, supra note 33 at para 76; Carrier Sekani, supra note 5 at para 44; Da'naxda'xw/Awaetlala First Nation v British Columbia (Minister of Environment), 2011 BCSC 620, [2011] 3 CNLR 188 at para 142; Adams Lake Indian Band $v$ Lieutenant Governor in Council, 2012 BCCA 333, [2012] 4 CNLR 1 at para 70.

Squamish Nation, ibid.

Supra note 79 at para 3.

Neskonlith, supra note 3 at para 64.

Arthur Pape, "The Duty to Consult and Accommodate: A Judicial Innovation Intended to Promote Reconciliation" in Morellato, supra note 50,313 at 315.

Fung, Giardini \& Miller, supra note 50 at 213. 
In addition to being prudent, consultation at an early stage is a legal requirement. In Dene Tha' First Nation v. Canada (Minister of Environment), ${ }^{252}$ Justice Phelan of the Federal Court held that there should have been consultation at an earlier stage of decision-making processes leading to the approval of a major project, the construction of the MacKenzie Gas Pipeline. The duty to consult was engaged when there was "strategic planning for [the] utilization of the resource' and ... '[d] ecisions made during strategic planning may have potentially serious impacts on Aboriginal right and title." ${ }^{253}$ As Dwight Newman has observed, if the consultation process is left until after the overall plan is developed and concerns itself with individual permits, this does not give an Indigenous group a reasonable opportunity to address the larger decision before facing the spectre of "death by a thousand cuts." ${ }^{254}$ Therefore, when local governments develop strategic, long-term land use plans, ${ }^{255}$ they should consult with the Indigenous peoples whose rights or title may be affected. ${ }^{256}$

Another reason why it is efficient to hold municipalities to a duty to consult is that otherwise, the only recourse against a failure to consult will be an action against the province. The duty to consult favours "negotiation and nation-to-nation relationships over judicial dispute resolution processes." 257 The duty is not meant to encourage litigation. Attacking a local decision at the provincial level is cumbersome and lacks an effective remedy if the municipal decision was not subject to provincial approvals. As Thomas Isaac has pointed out, municipalities enjoy a degree of autonomy from the provinces, and unless a province has expressly reserved the power to do so, provinces cannot interfere with how a municipality chooses to exercise its powers. ${ }^{258}$ In Squamish Nation, for example, the Court observed that once a province approves a municipality's OCP, "the Province has virtually no control over future OCP amendments or zoning decisions." ${ }^{259}$ Although a statute with retroactive effect could reverse a local decision that is otherwise final, usually realities "on the ground" would preclude this, because of foreseeable political fallout and prejudice to third parties who relied on the local decision.

Some have observed that a municipal duty to consult might take away from what should be "nation-to-nation" relationships between the Crown and Aboriginal peoples, might reduce the potential scope of consultation and accommodation, and could cause confusion about who is required to consult. ${ }^{260}$ These are reasonable concerns, but the relationship between the Crown and Aboriginal peoples has to be structured around the reality that the Crown in Canada exists as numerous governments at federal, provincial, and local levels, all of which have jurisdiction that overlap with the interests and jurisdiction of Indigenous governments.

2006 FC 1354, 303 FTR 106, aff'd 2008 FCA 20, 378 NR 251.

Ibid at para 106, citing Haida Nation, supra note 33 at para 76 [emphasis added by Phelan J].

Newman, supra note 58 at 54.

See the discussion in the text accompanying notes $210-14$, above

As Newman notes, a permit-by-permit approach to consultation may be impractical in any event and would likely create delays and other problems inimical to the goals of the duty to consult (supra note 58 at 54). This also addresses the British Columbia Court of Appeal's concern in Neskonlith that consultation about "mundane decisions," such as licences and permits, would be impractical (supra note 3 at para 72). If Aboriginal rights or interests are affected by such decisions, then consultation should have occurred earlier in the process.

Newman, ibid at 77.

Isaac, supra note 175 at 332, citing Hoddinott, supra note 173.

Supra note 246 at para 150.

See Ritchie, supra note 31, especially at 400, 414-19. On the "nation-to-nation relationship," see Imai \& Stacey, supra note 31 at 302, though they do not see leaving all consultation with the Crown as an efficient solution. 
In spite of broad statutory powers and purposes, sometimes municipalities may nevertheless lack sufficient capacity to consult and accommodate. Smaller municipalities may lack the necessary resources or expertise to consult, or even to assess the scope and strength of a claim to determine the appropriate depth of consultation. Since this constitutional duty must nevertheless be met, ${ }^{261}$ such a lack of capacity could be addressed with cooperation in the consultation process between local and provincial governments, as Imai and Stacey have proposed. ${ }^{262}$ They suggest that legislation could require municipalities to submit consultation plans to the relevant Ministry. If the consultation required exceeds the capacity of smaller municipalities, the province could provide the necessary assistance. ${ }^{263}$

Excluding any level of government from the duty to consult would conflict with the objectives of the duty to consult, and would impair Canada's ability to live up to its undertaking to uphold the United Nations Declaration on the Rights of Indigenous Peoples. ${ }^{264}$ In view of the important local role in land use planning and development, the consultation and joint processes required by the Declaration cannot be met without a prominent municipal role. There is an important and growing body of planning research that is recognizing the importance of direct engagement between local planners and Indigenous communities. ${ }^{265}$ Although for the most part that work is beyond the scope of this article, a particularly cogent point is that Indigenous peoples are not just neighbours of municipalities, they have rights and interests that overlap local boundaries. For local planners, this means that better outcomes can be expected when relationships with Indigenous peoples are based on collaboration, rather than consultation that treats Indigenous peoples as just "stakeholders." 266 This is especially important when the jurisdiction of local planners overlaps with actual or claimed Aboriginal title rights. ${ }^{267}$ As Canada moves toward recognizing the jurisdiction of Indigenous nations, it should be increasingly apparent to all governments that, in the long run, collaboration will work better than consultation. ${ }^{268}$

\section{CONCLusion}

Municipalities once had only narrow powers and served their provincial masters to provide local services and to administer provincial policies. In the past two decades, provincial legislatures have given municipalities the powers, purposes, flexibility, and legal status of an order of government. A series of Supreme Court of Canada decisions have supported this shift by recognizing the important role played by local governments in a

261 Carrier Sekani, supra note 5 at para 63. See also Chippewas of the Thames, supra note 29 at para 32; Clyde River, supra note 7 at para 30.

Supra note 31 at $308-10$.

Ibid at 309-10.

Supra note 2. See also the text accompanying notes 238-41. We owe this insight to Ed Wensing, personal communication, and Ed Wensing \& Libby Porter, "Unsettling Planning's Paradigms: Towards a Just Accommodation of Indigenous Rights and Interests in Australian Urban Planning?” (2016) 53:2 Australian Planner 91 at 98.

265 See e.g. Ryan C Walker, "Improving the Interface Between Urban Municipalities and Aboriginal Communities" (2008) 17:1 Can J Urban Research Supplement 20; Porter \& Barry, supra note 109; Ryan Walker, Ted Jojola \& David Natcher, eds, Reclaiming Indigenous Planning (Montreal \& Kingston: McGill-Queen's University Press, 2013); Wensing \& Porter, ibid. See R Ben Fawcett, Ryan Walker \& Jonathan Greene, "Indigenizing City Planning Processes in Saskatoon, Canada” (2015) 24:2 Can J Urban Research 158; Porter \& Barry, ibid at 110.

267 See e.g. Wensing \& Porter, supra note 264 at 94ff; Porter \& Barry, ibid at 106-14.

268 For an outline of the New Zealand model which mandates local governments to collaborate with Maori, see supra notes 117-19 and accompanying text. 
democracy, and by interpreting local powers generously so municipalities can fulfil their purposes.

Modern municipalities are democratic governments with broad powers over a defined territory, including jurisdiction over land use and development. Experience has shown that their decisions can affect Indigenous interests, and that better relationships and better outcomes result from consulting and collaborating with Indigenous governments. Devolving governmental powers to this extent without incorporating corresponding constitutional obligations would be inconsistent with the honour of the Crown.

The Supreme Court's jurisprudence has established that an administrative body can trigger the duty to consult, and if it has sufficient powers, the body can also fulfill the duty. The most important way in which modern municipalities differ from administrative bodies is that they are an order of government with broad and flexible powers. This difference magnifies the importance of holding these governments to the requirements of section $35^{269}$ and the honour of the Crown, including the duty to consult.

If the law's conception of the Crown is too narrow to include local governments, then the transfer of governmental authority will only be consistent with the honour of the Crown if the law presumes that statutes devolving governmental authority also delegate constitutional obligations like the duty to consult. If a province expressly excluded the duty to consult from its delegation of governmental authority, it would be incumbent on the province to ensure that the duty is still satisfied.

After asserting sovereignty over Indigenous peoples, the Crown delegated a broad spectrum of the powers flowing from that sovereignty to local governments. If the duty to consult does not accompany the transfer of these sovereign powers, then the Crown will not be able to play its essential role of protecting Aboriginal rights and promoting reconciliation. Actions taken by local governments can have tragically negative or profoundly positive effects on the relationship between Canada's Indigenous peoples and society as a whole. The effects are more likely to be positive if local governments know that engaging with Indigenous communities on matters that affect them is not only good public policy - it is also the law. 